Target Journal: Biocontrol Science and Technology

Original article

\title{
Cross-correlation analysis of invasive mango mealybug and its associated natural enemies in relation to meteorological factors: implications for biological control
}

Chrysantus Mbi Tanga ${ }^{\mathrm{a}, \mathrm{b}^{*}}$, Samira Abuelgasim Mohamed ${ }^{\mathrm{a}}$ Govender Prem $^{\mathrm{b}, \mathrm{c}}$, Daisy Salifu ${ }^{a} \&$ Sunday Ekesi ${ }^{a}$

${ }^{a}$ International Centre of Insect Physiology and Ecology (icipe), P.O. Box 30772-00100 GPO, Nairobi, Kenya; Tel.: +254-20-8632000; Fax: +254-20-8632001/2;

${ }^{b}$ Department of Zoology and Entomology, University of Pretoria, South Africa 'Faculty of Health Sciences, Sefako Makgatho Health Sciences University (SMU), P.O. Box 163, Ga-Rankuwa 0221, South Africa.

Running title: Impact of climatic factors on mealybug outbreaks

*Correspondence to: C.M. Tanga, Tel.: + 254-20-8632151; Fax: +254-20-8632001/2; Email: ctanga@icipe.org 


\section{ABSTRACT}

Damage caused by invasive downey snow line mealybug, Rastrococcus iceryoides Green (Hemiptera: Pseudococcidae) has been reported to vary between 30\% to complete crop loss where no control measure is applied. The current studies seek to determine factors influencing $R$. iceryoides population outbreaks, parasitoid - host and predator - prey relationships as well as predict optimal management strategies through weather modelling over a period of 28 months from 2008 to 2010 in Tanzania. The highest incidence of $R$. iceryoides was recorded during the dry season coinciding with the major mango fruiting season. The relationship between $R$. iceryoides and the parasitoid was positive but not significant, which implies the influence on outbreaks was negligible probably due to low percent parasitism $(<12 \%)$. However, the predator abundance was directly and significantly related to that of $R$. iceryoides. Average temperature, average relative humidity, rainfall, and $R$. iceryoides abundance were autocorrelated to each other. Cross-correlation coefficients vary significantly from - 0.286 to 0.589 for the pair-variable between $R$. iceryoides, temperature, relative humidity, rainfall, parasitism and predators. Our findings showed that temperature was the key climatic variable that significantly influenced $R$. iceryoides outbreaks while rainfall was significantly negatively associated with the pest. Time series analyses show $R$. iceryoides population increased 4 months after an increase in average temperature in all the sites, 11 months after rainfall and 11 months after relative humidity in Kibaha and Dar es Salaam, respectively. Our findings revealed that $R$. iceryoides is an excellent target for classical biological control. Thus, the importation of promising co-evolved parasitoids specific to $R$. iceryoides from the aboriginal home is crucial in formulating an efficient and sustainable management approaches against the invasive mealybug pest in mango agro-ecosystems.

KEYWORDS: Mango mealybug pest; Rastrococcus iceryoides Green; insect-environment relationships; time series analysis; pest management strategies 


\section{Introduction}

Rastrococcus iceryoides Green (Hemiptera: Pseudococcidae) was inadvertently introduced from Southern Asia to Africa in the early 1990s (CABI, 2000). Rastrococcus iceryoides together with its close relative $R$. invadens Williams (Homoptera: Pseudococcidae) are regarded as the two most economically significant invasive mango mealybug pests in Africa originating from Southern Asia. Rastrococcus invadens caused severe damage on mango in West and Central Africa but was controlled using two exotic parasitoids, Gyranusoidea tebygi Noyes and Anagyrus mangicola Noyes (both Hymenoptera: Encyrtidae) imported from India (Bokonon-Ganta and Neuenschwander, 1995; Noyes, 1988). Rastrococcus iceryoides is currently limited to East Africa, especially in Tanzania, Coastal Kenya and Northern Malawi. In these countries, it remains one of the most destructive mealybug pests of fruit trees, including Mangifera indica Linn. (mango) in the family Anacardiaceae and other ornamental plants (Williams, 1989; Luhanga \& Gwinner, 1993; CABI, 2000; Tanga, 2012). When R. iceryoides was reported for the first time in Africa, efforts were channelled toward identifying a potential indigenous natural enemy capable of controlling the invasive pest without expending resources in foreign exploration trips for natural enemies to release in classical biological programme in affected areas. These efforts failed considerably because the extensive sampling in Kenya and Tanzania, yielded no parasitoid that was effective against the pest (Tanga, 2012). Thus, the importation of $R$. iceryoides specific coevolved natural enemies from the native range of the pest become crucial to form new association with the indigenous natural enemies to combat the pest as it expands it host range. It is undeniable that such interactions are key in shaping future structures of parasitoid population dynamics in pest control (Godfray, 1994). Effective biological control relies on parasitoids that are highly efficient 
in foraging from a host to minimize time and energy expended in such exercise (Godfray, 1994), which was not the case with the indigenous parasitoids in Kenya and Tanzania.

Surveys conducted in Kenya and Tanzania revealed that $R$. iceryoides has a broad host range, attacking 29 wild and cultivated host plant species belonging to 16 families. Twenty-one (21) of these plants were first reported for the first time as host of R. iceryoides, out of which 18 are native to Africa (Tanga et al., 2015). The broad host range reported in Africa suggests that $R$. iceryoides is spreading rapidly and may continue to expand its host range. Mealybug outbreaks may lead to delayed flowering, early drop of floral spikes and young leaves, drying of young fruits, reduced fruit setting, early ripening of immature fruits, rind pitting and scarring, and slow growth of new branches accompanied by severe dieback on heavily infested plant parts (Tanga, 2012). Large amounts of excreted honeydew may accumulate leading to the growth of sooty mould, which in turn results in drastic reduction in photosynthesis, reduced plant growth, flowering and fruiting, and premature leaf drop (Tanga, 2012). In Tanzania, Kenya and Malawi, damage levels can range from $30 \%$ to total crop failure in orchards lacking control measures (CABI, 2000; Tanga, 2012). Members of the genus Rastrococcus frequently become major pests in newly invaded areas (Bokonon-Ganta \& Neuenschwander, 1995; Tanga, 2012). For example, R. invadens was accidentally introduced to Ghana (Moore, 1992; Nébié et al., 2016) and mango losses were over 80\%. At research stations in Korhogo-Lataha, Côte d'Ivoire, and in farmers' orchards, yield losses ranged from 53 to $100 \%$ (Hala et al., 2004; Nébié et al., 2016). The pest is currently being controlled by insecticidal sprays, heavy pruning and burning of infested plant parts (Willink \& Moore, 1988; Tanga, 2012). Resource-poor farmers in affected areas cannot buy and use insecticides due to their prohibitive cost. In addition, $R$. iceryoides is difficult to manage with insecticides due to their covering of hydrophobic wax (Blumberg \& Van Driesche, 2001; Derzelle 
et al., 2004). The inefficiency of the insecticides coupled with their high cost has rendered mango cultivation uneconomical, leading to the abandonment of mango production in severely affected areas (Tanga, 2012).

The distribution and variation in mealybug populations is largely dependent upon environmental conditions (DeBach, 1949; Amarasekare et al., 2008). Environmental conditions also may influence natural enemy populations (Arif et al., 2006; Chaudhari et al., 1999). Therefore, to develop an early warning weather-based system for the invasive pest in a specific agroecosystem, it is therefore necessary to have basic information associating population dynamics with meteorological variables such as temperature, relative humidity and rainfall to determine the optimal time for applying control measures.

A thorough understanding of the interactions between environmental conditions and the pest and natural enemy population dynamics is a prerequisite for successful development of a weather-based pest forecasting model. It is anticipated that that environmental factors play a key role in $R$. iceryoides outbreaks and may also affect its associated natural enemies. In this study, we seek to determine factors influencing the pest $R$. iceryoides population outbreaks, parasitoid-host (R. iceryoides) and predator-prey ( $R$. iceryoides) relationships as well as predict optimal management strategies through weather modelling over a period of 28 months from 2008 to 2010 in Kibaha (Pwani region) and Kinondoni (Dar es Salaam region), Tanzania. Results from this study will enhance forecasting of $R$. iceryoides outbreaks, allowing community-based phytosanitary authorities to better distribute their limited resources to $R$. iceryoides management programs at national and regional levels. 


\section{Materials and Methods}

\section{Mealybug monitoring and weather data}

This study was carried out along the coastal belt of Tanzania (latitude $1^{\circ}$ to $11^{\circ} 45^{\prime} \mathrm{S}$ and longitude $29^{\circ} 21^{\prime}$ to $40^{\circ} 25^{\prime} \mathrm{E}$ ), which is characterised by tropical conditions. The sampling was conducted in two commercial mango orchards located in Kibaha ( $06^{\circ} 43^{\prime} 84^{\prime \prime} \mathrm{S} ; 038^{\circ} 46^{\prime} 07^{\prime \prime} \mathrm{E}, 162 \mathrm{~m}$ above sea level) and Kinondoni, Dar es Salaam (06 45' 80" S; 039 06' 25" E, 79 m a. s. 1). The distance between the two project benchmark sites was $48.66 \mathrm{~km}$. The mango trees were reported to have been infested with the mango mealybugs since 2004 (i.e., four years prior to commencement of research activities). We ensured that mango trees in the two study localities were maintained under the same agricultural practices and were never sprayed with insecticidal products for the preceding four years. The conventional orchard spacings (in-row $\mathrm{x}$ between-row) of $8 \times 8 \mathrm{~m}$ (156 trees/hectare) was commonly adopted in both study sites for the popular export cultivars, Apple mango and Tommy Atkins. In the orchards, pruning programs were regularly carried out to permit better light dispersal through the canopy, where as to control tree size, rows of tree branches were severely cut back once the canopies were considered to have become too large.

The nymphs and adult populations of $R$. iceryoides were monitored weekly using sampling methodology similar to that described by Pitan et al., (2000), Bokonon-Ganta \& Neuenschwander (1995) and Tanga et al., (2015). Destructive field sampling was carried out for 112 consecutive weeks (2008 - 2010). At each location, 15 rows, each with approximately 67 trees along a $536 \mathrm{~m}$ transect were randomly selected with sampling points every $16 \mathrm{~m}$ from the most northerly position of the transect. From each sampling position along the transect, 20 mango trees were randomly selected at fixed distances from each other and marked with flagging ribbon before beginning the sampling. Tall mango trees with height varying from $1-5 \mathrm{~m}$, samples were collected at 
approximately height of $1-2 \mathrm{~m}$ from the ground. For mango trees with $5-10 \mathrm{~m}$ height, sampling was conducted within $1-3.2 \mathrm{~m}$ height. For tall trees, hedge clippers were attached to long wooden poles to access sampling units far away ( $\sim 2 \mathrm{~m}$ from the ground). For each mango tree, sampling units comprised of 20 leaves, 5 twigs ( $\sim 15 \mathrm{~cm}$ long) and 5 fruits randomly selected within a $1 \mathrm{~m}^{2}$ surface area to evaluate mealybug abundance. To ensure samples were not from same position of the tree, we changed the order of sampling around each plant (bottom to top and vice versa). No plant was sampled twice during the survey in each location.

The different sampling parts from each plant were kept separately in translucent plastic bags, which were later transported in cool boxes to the laboratory for further analysis. All the mealybug life stages observed per plant portion were carefully counted and recorded according per sampling date. Counting of these life stages was facilitated with the help of a head lens (Donegan OptiVISOR LX Binocular Magnifier-Lensplate \#10, Magnification 3 x 9 at 10" focal length) or in some cases by stereomicroscope [Leica MZ 125 Microscope (Leica Microsystems Switzerland Limited)]. A Toshiba 3CCD camera was attached to the microscope with the aid of an Auto-Montage software (Syncroscopy, Synoptics Group, Cambridge, UK) at 25X magnification.

In both areas, rainfall pattern varied considerably during the season between February and June. The temperature and relative humidity $(\mathrm{RH})$ were generally high, with mean minimum temperature of $23.34^{\circ} \mathrm{C}$ and mean maximum temperature of $31.93^{\circ} \mathrm{C}$; while the average minimum RH was $63.20 \%$ and average maximum RH was $83.82 \%$. In this region, the seasons are well defined: northeast monsoon (December to February - this period is hot and comparatively dry); the long rains (March to May), and the short rains (November to December) and the southwest monsoon [June to October (coldest and driest)] (EON, 2011). Records of the main climatic factors: 
day-to-day minimum and maximum relative humidity, temperatures, and total rainfall were obtained from the central meteorological and agricultural research station in Kibaha $\left(06^{\circ} 46^{\prime} 42^{\prime \prime}\right.$ S; $038^{\circ} 58^{\prime} 21^{\prime \prime}$ E, 169 m a. s. 1) and from the Dar es Salaam Airport weather station along Julius Nyerere road, Dar es Salaam $\left(06^{\circ} 52^{\prime} 51^{\prime \prime}\right.$ S; 039 $12^{\prime}$ 07" E, 55 m a. s. 1). Daily values of these weather parameters were then averaged to correspond with the weekly sampling dates.

\section{Parasitoid data collection}

In the laboratory, the different plant parts were inspected and mummified $R$. iceryoides carefully removed with a fine hair camel brush. The mummies were counted and stored individually in gelatin capsules (number 00) until parasitoid emergence was observed. The remaining mealybugs were further reared on butternuts in transparent plastic containers $(22.5 \times 20 \times 15 \mathrm{~cm})$ at the National Biological Control Program (NBCP), Kibaha, Tanzania. This was to check for additional parasitized mealybugs that had not attained the stage of mummification at the time of the survey per sampling date and plant part in each locality. In each cage, two openings of $10 \mathrm{~cm}$ diameter were curved out on both sides. Sleeves were designed with organza material $(0.1 \mathrm{~mm}$ size $)$ and fixed on the openings for sufficient ventilation. Another opening (15 cm diameter) was constructed on the roof of each cage and screened as described above. On the roof of each, we applied streaks of $50 \%$ honey solution as food for emerged parasitoids. The experimental set up was maintained at ambient temperatures of $28 \pm 1{ }^{\circ} \mathrm{C}, 70 \% \mathrm{RH}$ and $12: 12 \mathrm{~L}$ : D photoperiod. Mummies mealybugs in the cages were checked daily for emergence until the parasitoid wasps ceased to emerge. The emerged parasitoids were given water ad libitum on cotton balls in Petri dishes. Emerged parasitoids were fed for a period of 6 days to allow for full development of body colorations. The parasitoids were frozen at $-20^{\circ} \mathrm{C}$ before preserving in $70 \%$ ethanol. The samples of emerged 
parasitoids were labelled with their respective plant part and sampling date for each locality. The parasitoid samples were initially identified at Annamalai University, India and later confirmed at the Agricultural Research Council (ARC), Pretoria, South Africa.

\section{Predator data collection}

Kibaha and Dar es Salaam fields were sampled 120 times at weekly intervals for predators of $R$. iceryoides using the beat sheet technique (Wade et al., 2006). This involved beating five randomly selected branches of each selected mango tree at fixed distances over a $1 \mathrm{~m}^{2}$ cloth screen using a $60 \mathrm{~cm}$ long stick. Sampling was carried out within the early hours of morning from 8:00 am and completed by 13:00 PM. This period was selected because many insects quickly fly off from the plant when disturbed, especially when temperatures are high around $25-30^{\circ} \mathrm{C}$ (Garcia et al., 1982; Knutson et al., 2008). Sampling was conducted by a team of two workers, one-person beating the plant part and the other holding the sheet to trap dislodged insects. This technique was conducted for each host plant and predators dislodged were collected in a 42-mm Buchner funnel, which were later transferred into a glass jar with $90 \%$ ethanol. Immature stages of the predators dislodged during the survey were further reared in the laboratory on mealybugs reared on butternuts in Poly (methyl methacrylate) (PPMA) [Perspex cages measuring 15 x 20 x $15 \mathrm{~cm}$ )] until they developed into adults, which were later identified and counted. The rearing process was carried out in the laboratory set at the National Biological Control Program (NBCP), Kibaha, Tanzania. The predators collected were further taxonomically identified by a specialist in the University of Dar es Salaam. 


\section{Statistical analyses}

Descriptive statistics of all the weather variables, mealybug abundance, parasitism rates and predators were calculated. The monthly incidence of $R$. iceryoides in both study sites were treated as a dependent variable, while the predator abundance, parasitism rates and meteorological variables such as weekly average temperature, weekly average temperature, average relative humidity and rainfall were considered as independent variables. A $\chi^{2}$ goodness of fit test was used to establish if the mealybug infestation levels and percent parasitism of the mealybugs were the same on the different plant parts. The weather factors like average temperature, average relative humidity, and rainfall data were recorded from the study location every day and month. The influence of weather factors on population density of $R$. iceryoides and its associated natural enemies were analysed by a simple correlation study and coefficients were worked out for the period of the study. In order, to investigate the simultaneous influence of the climatic factors on $R$. iceryoides incidence, associated biocontrol agents and weather parameters, a multiple linear regression analysis was used.

Temporal interdependence of insect abundance, percent parasitism, relative humidity $(\mathrm{RH})$, temperature and rainfall were quantified using correlogram $\rho(h)$, also known as autocorrelation function (Venables \& Ripley, 2002). The autocorrelation function was defined as a ratio of sample covariance function $C(h)$ and quantification of variance $\sigma^{2}$. The formula used to determine the covariance $C(h)$ and autocorrelation function $\rho(h)$ are shown below:

$C(h)=\frac{1}{n(h)-1} \sum_{i=1}^{n(h)}\left[z\left(x_{i}\right)-\bar{x}\right]\left[z\left(x_{i}+h\right)-\bar{x}\right]$

$\rho(h)=\frac{C(h)}{\sigma^{2}}$ 
Here, $n(h)$ in the equation (1) is defined as pairs of sample variables at time $h, z(x)$ was described as the value of the variables at time $x ; z(x+h)$ represented variable value at time $x+h$, and $h$ was the lag (months) among the measurements, while $\bar{x}$ was the average value of the different measurements, $x$ and $h$ were the vectors. Cross-correlation function $\gamma_{x y}(h)$, clearly described the statistical measurement of timing the movement and closeness of the arrangement in a straight line between two dissimilar sets of information of time series, which was described by the crosscovariance function $C_{x y}(h)$ (Venables and Ripley, 2002):

$C_{x y}(h)=\frac{1}{n(h)} \sum_{i=1}^{n(h)}\left(x_{i+h}-\bar{x}\right)\left(y_{i}-\bar{y}\right)$

$\gamma_{x y}(h)=\frac{C_{x y}(h)}{\sigma_{x} \sigma_{y}}$

Here, in equation (3), $n(h)$ represent the sum of pairs of sample points at time $h$ apart, $x i+h$ was the estimation of $x$ at time $i+h, y i$ was the measure of $y$ at time $i, h$ was the time between measures, $x$ and $y$ described the averages for $x$ and $y$, respectively, while $i$ and $h$ represented the vectors. In equation (4), $\sigma_{x}$ and $\sigma_{y}$ represented the standard deviations of $x$ and $y$, respectively.

The values of autocorrelation and cross correlation functions ranged from -1 to 1 . The nearer the autocorrelation estimated value is to 1 or -1 , the more closely related are the 2 -values of that similar variable at times $x_{i}$ and $x_{i+h}$. Likewise, the nearer the cross-correlation value is to 1 (or -1 ), the more closely related the information of the 2 datasets. The autocorrelation coefficient for mealybug abundance, parasitoid parasitism, $\mathrm{RH}$, rainfall and temperature were estimated using the acf function $\mathrm{R}$ and the cross-correlation coefficient were estimated using the $c c f$ function of $\mathrm{R}$. The significance of autocorrelation and cross-correlation time lag (Li et al., 2001; 2002; Salomon 
et al., 2004) was determined at $95 \%$ confidence threshold. The predicted $R$. iceryoides population densities were estimated using generalized linear model, which assumed a negative binomial distributional error for the count data. All statistical analyses were implemented using $\mathrm{R}$ version 2.15.2 software (R Development Core Team, 2012).

\section{Results}

\section{Temporal pattern of climatic temperature, rainfall and relative humidity}

The temporal pattern of the weekly average temperature, total rainfall and relative humidity in Dar es Salaam and Kibaha showed similar trend throughout the study duration. In Dar es Salaam, the maximum temperature was $31.99 \pm 0.18^{\circ} \mathrm{C}$, minimum temperature $23.37 \pm 0.20^{\circ} \mathrm{C}$ and mean temperature $27.68 \pm 0.18^{\circ} \mathrm{C}$ [mean and standard error (SE)] during $R$. iceryoides incidence across standard meteorological weeks. The weekly total rainfall was low with significant variation throughout the study period ranging from 0 to $259.2 \mathrm{~mm}$ in Kibaha and 0 to $264.7 \mathrm{~mm}$ in Dar es Salaam. Total rainfall throughout the study period was $1164 \mathrm{~mm}$ in Kibaha and $1284 \mathrm{~mm}$ Dar es Salaam. In Kibaha, the maximum, minimum and mean temperatures were $30.66 \pm 0.16^{\circ} \mathrm{C}$, $22.78 \pm 0.25^{\circ} \mathrm{C}$ and $27.22 \pm 0.22^{\circ} \mathrm{C}$, respectively. The maximum relative humidity $(\mathrm{RH})$ on the other hand in Dar es Salaam and Kibaha was high $(83.78 \pm 0.82 \%$ and $82.11 \pm 1.73 \%$, respectively) with little variation. The minimum RH in Dar es Salaam was $63.0 \pm 1.11 \%$ and the average RH was $73.39 \pm 0.90 \%$, while in Kibaha minimum and mean $\mathrm{RH}$ were $61.47 \pm 1.14 \%$ and $70.98 \pm 2.45 \%$, respectively. 


\section{Temporal patterns of $R$. iceryoides, percent parasitism by Anagyrus pseudococci and predators}

The mean population density of mango mealybug $R$. iceryoides on the leaves, twig and fruits across the consecutive seasons of 2008 and 2011 in relation to weekly rainfall in Kibaha and Dar es Salaam is presented in Figure 1A and Figure 1B, respectively. The $R$. iceryoides abundance followed an annual cycle, that was harmonized with the major mango production period (fruiting season) of each year. Results revealed that in general $R$. iceryoides population were higher during the major mango season in 2009 and 2010 in Kibaha than in Dar es Salaam. Peak incidence occurred during the dry season (December-February) each year on all the plant parts. The population declined sharply with decrease in temperature coming after the onset of the rainy season, which starts in March and ends in May. Thereafter, infestation remained low throughout the cold southwest monsoon (June-October) until the next mango season in December. The difference in $R$. iceryoides abundance over the study period on the different plant parts was significant in Dar es Salaam $(F=33.58 ; d f=2 ; P<0.0001)$ and in Kibaha $(F=154.23 ; d f=2 ; P$ $<0.0086)$. The mealybug abundance in both locations was significantly different as well $(\mathrm{F}=$ $25.85, \mathrm{df}=1, \mathrm{P}<0.0001)$.

In Dar es Salaam, the peak of $R$. iceryoides population was recorded on the $11^{\text {th }}$ of January 2009 (mean temp. of $27.9^{\circ} \mathrm{C}$, mean $\mathrm{RH}$ of $66.6 \%$, and no rainfall), with $148.6 \pm 40.6$ twig $^{-1}$ and $82.6 \pm 13.4$ leaf $^{-1}$. The minimum weekly abundance was recorded on the $20^{\text {th }}$ of February 2009 (mean temp. of $27.6^{\circ} \mathrm{C}$, mean $\mathrm{RH}$ of $72.8 \%$, and rainfall of $63.2 \mathrm{~mm}$ ) on the twigs $(10.3 \pm 3.0$ mealybugs twig ${ }^{-1}$ ) and on the $8^{\text {th }}$ of March 2009 (mean temp. of $27.8^{\circ} \mathrm{C}$, mean RH of $73.5 \%$, and rainfall of $30.8 \mathrm{~mm})$ on the leaf $\left(10.9 \pm 5.4\right.$ mealybugs leaf $\left.^{-1}\right)$ and fruits $\left(4.6 \pm 1.9\right.$ mealybugs fruit $\left.^{-1}\right)$ coinciding with the raining season (Figure 1B). Similarly, in 2010, the highest infestation levels by $R$. iceryoides on the twigs $\left(75.7 \pm 21.2\right.$ mealybugs twig $\left.^{-1}\right)$ was recorded on the $11^{\text {th }}$ January 2010 


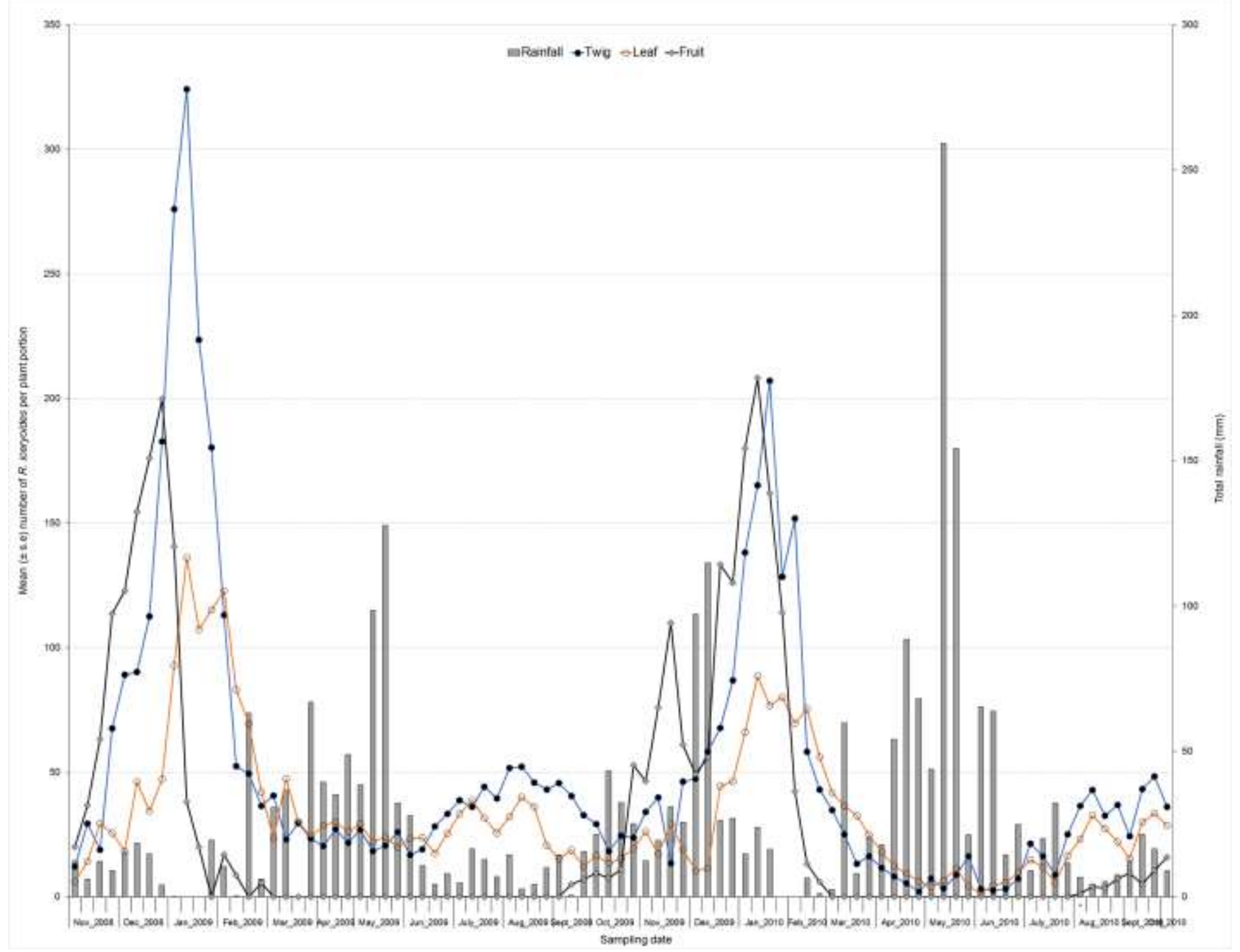

Figure 1. Seasonal fluctuation of Rastrococcus iceryoides (all stages combined) on the twigs, leaves and fruit with corresponding rainfall (mm) in Kibaha. 
(mean temp. of $27.4^{\circ} \mathrm{C}$, mean $\mathrm{RH}$ of $81.5 \%$, and $30.3 \mathrm{~mm}$ of rainfall) while that on the leaves $\left(86.2 \pm 14.1\right.$ mealybugs leaf $\left.{ }^{-1}\right)$ and fruits $\left(82.6 \pm 30.8\right.$ mealybugs fruit $\left.^{-1}\right)$ was recorded on the $27^{\text {th }}$ of January 2010 (mean temp. $28.4^{\circ} \mathrm{C}$, mean $\mathrm{RH}$ of $69.7 \%$, and $0 \mathrm{~mm}$ rainfall). In Kibaha, two major peaks of outbreak were observed during the period of 2009 and 2010. In 2009, the maximum abundance of $R$. iceryoides on the twigs $\left(324.1 \pm 82.3\right.$ mealybugs twig $\left.^{-1}\right)$ and leaves $(136.1 \pm 17.9$ mealybug leaf ${ }^{-1}$ ) were recorded on the $10^{\text {th }}$ of January (mean temp. of $27.9^{\circ} \mathrm{C}$, mean $\mathrm{RH}$ of $66 \%$, and $0 \mathrm{~mm}$ rainfall). In 2010, the maximum infestation levels on the leaves $(88.5 \pm 13.7$ mealybugs leaf $\left.{ }^{-1}\right)$ and the fruits $\left(178.4 \pm 54.1\right.$ mealybug fruit $\left.{ }^{-1}\right)$ were recorded on the $10^{\text {th }}$ of January (mean temp. $27.7^{\circ} \mathrm{C}$, mean $\mathrm{RH}$ of $82 \%$, and $23.9 \mathrm{~mm}$ rainfall), while that on the twigs was $207.2 \pm 54.6$ mealybugs twig ${ }^{-1}$ on the $18^{\text {th }}$ of January (mean temp. of $28.3^{\circ} \mathrm{C}$, mean RH of $78.7 \%$, and $16.3 \mathrm{~mm}$ rainfall). In Kibaha, the population of mealybugs recorded on the twigs, leaves and fruits differed significantly $(\chi 2=123.4 ; d f=2 ; P<0.0001)$.

For the parasitoid, A. pseudococci, a total of 3,421, 10,357 and 261 mummified $R$. iceryoides were collected from the twigs, leaves and fruits, respectively, accounting for $5.5 \pm 0.2 \%$, $6.5 \pm 0.1 \%$ and $3.4 \pm 0.4 \%$ parasitism in Dar es Salaam. In Kibaha, the number of mummified mealybugs on the twigs $(1,537)$, leaves $(6,239)$ and fruits $(2,44)$ accounted for a mean percent parasitism of $6.4 \pm 0.3 \%, 7.1 \pm 0.2 \%$ and $4.9 \pm 0.6 \%$, respectively. The seasonal fluctuation of percent parasitism in Kibaha and Dar es Salaam was slightly similar to that of the host $R$. iceryoides (Figure 2A and Figure 2B). The percent parasitism of $R$. iceryoides by $A$. pseudococci was quite low at the beginning of the season in December 2008 with gradual increase in January 2009 to reach its peak in February 2009, which coincides with the dry season. The percent parasitism on the different plant parts in Dar es Salaam and Kibaha were significantly different $(F=33.58 ; d f=1,2 ; P<$ 0.0001 and $F=154.23 ; d f=1,2 ; P<0.0086$, respectively). 


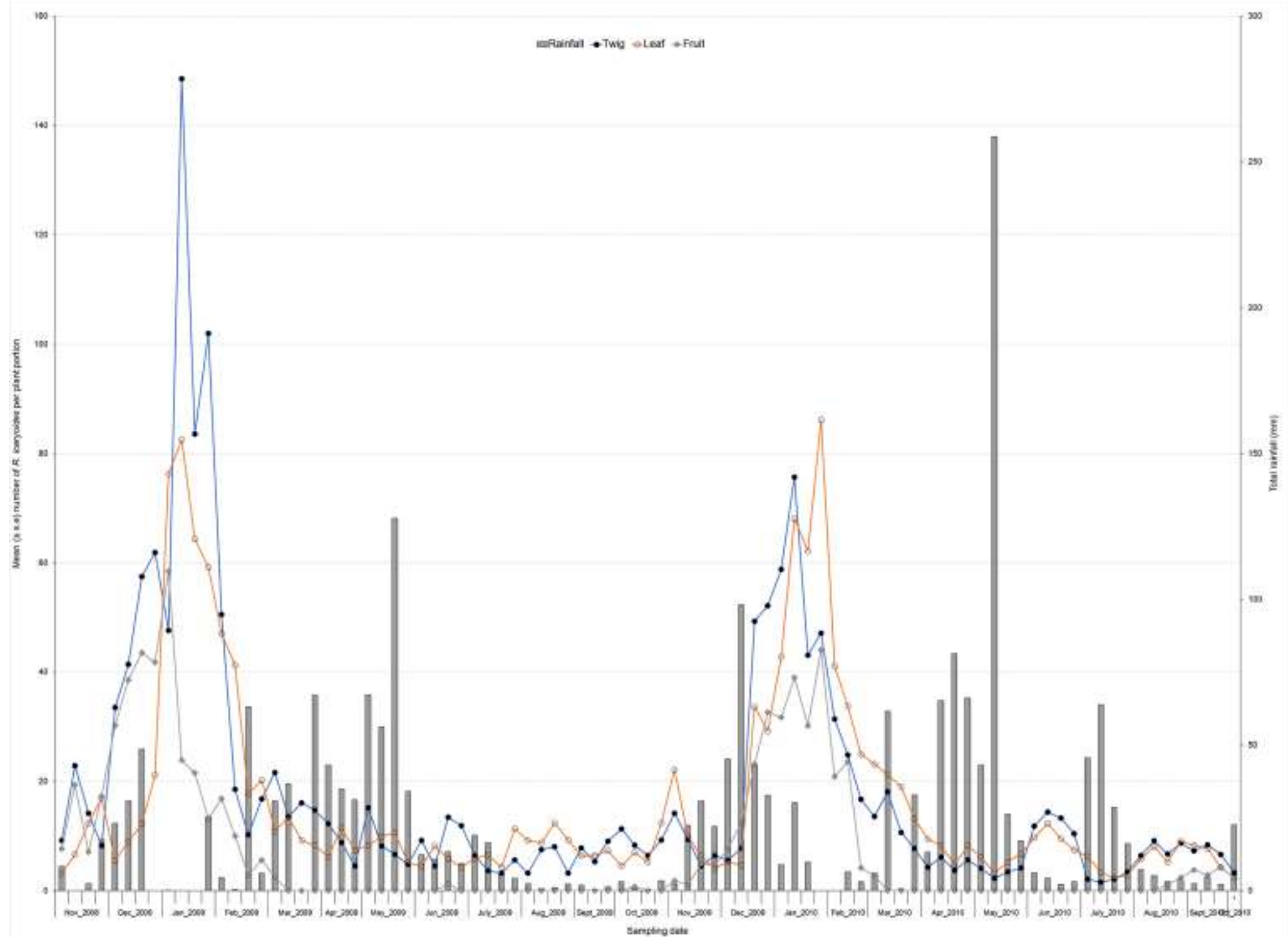

Figure 2. Seasonal fluctuation of Rastrococcus iceryoides (all stages combined) on the twigs, leaves and fruit with corresponding rainfall (mm) in Dar es Salaam. 
In Kibaha, a total of 19 species of predators were found preying on $R$. iceryoides throughout the study period. Six major predator species recorded during the survey belonged to the family Coccinellidae: Cryptolaemus montrouzieri Mulsant (1.42\%), Hyperaspis amurensis Weise (1.27\%), Hyperaspis bigeminata Randall (12.11\%), Exochomus nigromaculatus Goeze (3.47\%), Chilocorus renipustulatus Scriba (15.72\%), Chilocorus nigrita Fabricius (31.23\%); one Lycaenidae (Spalgis lemolea Druce) (9.07\%); one Drosophilidae (Cacoxenus perspicax Knab) (20.89\%). Other minor predators accounting for less than $<1 \%$ of the total collection included Pyroderces badia Hodges (Lepidoptera: Cosmopterigidae), Hemerobius sp. (Neuroptera: Hemerobiidae), Cheiracanthium virescens Sundevall (Arachnida: Clubionidae), and other coccinelids: Rodolia limbata Motschulsky, Rodolia pumila Weise, Micraspis sp., Propylea dissecta Mulsant, Propylea 14-punctata Schachbrett-Marienkäfer, Telsimia nitida Chapin, Harmonia dimidiata Fabricius and Hyperaspis sp. In Dar es Salaam, eleven species of predators were recorded. In the order of their importance they included: $C$. nigrita $>H$. bigeminata $>C$. renipustulatus $>$. . perspicax $>$ E. nigromaculatus $>C$. montrouzieri $>$ H. amurensis $>$ R. pumila $>$ S. lemolea $>$ Hyperaspis sp. $>$ R. limbata. The abundance of the predators recorded was positively and significantly influenced by temperature (Wald $=11.22 ; P=0.0051)$. In both study sites, the population of the predators was observed to increase in a density dependant manner together with that of their prey, R. iceryoides and the highest incidence of predator activities were recorded between the month of December and February across the study period (Supplementary Table 1 and Table 2), which coincides with the dry season. 
Table 1: Descriptive statistics of $R$. iceryoides infestation; percentage parasitism by the parasitoid Anagyrus pseudococci and weather parameters.

\begin{tabular}{|c|c|c|c|c|c|c|c|c|}
\hline Locality & Variable & Mean & S. E & $\mathrm{CV}$ & Maximum & Minimum & Kurtosis & Skewness \\
\hline \multirow{14}{*}{ Dar es Salaam } & Mealybug twig ${ }^{-1}$ & 29.84 & 5.022 & 106.4 & 148.6 & 1.55 & 3.381 & 1.77 \\
\hline & Mealybug leaf ${ }^{-1}$ & 27.31 & 3.76 & 87.08 & 86.2 & 3.475 & 0.0462 & 1.103 \\
\hline & Mealybug fruit ${ }^{-1}$ & 24.88 & 4.859 & 123.6 & 109.6 & 0 & -0.0892 & 1 \\
\hline & Percent parasitism_twig ${ }^{-1}$ & 6.875 & 0.522 & 48.03 & 13.66 & 2.2 & -0.782 & 0.597 \\
\hline & Percent parasitism_leaf ${ }^{-1}$ & 6.272 & 0.429 & 43.21 & 14.66 & 2.68 & 0.974 & 1.052 \\
\hline & Percent parasitism_fruit ${ }^{-1}$ & 3.341 & 0.566 & 107.2 & 11.11 & 0 & -1.068 & 0.562 \\
\hline & Predator abundance & 31.21 & 4.102 & 83.69 & 102 & 0 & 1.090 & 1.318 \\
\hline & Minimum temperature & 23.37 & 0.199 & 5.388 & 25.49 & 19.83 & 1.192 & -1.242 \\
\hline & Maximum temperature & 31.99 & 0.182 & 3.602 & 33.93 & 29.56 & -0.679 & -0.439 \\
\hline & Average temperature & 27.68 & 0.179 & 4.096 & 29.49 & 25.01 & 0.222 & -0.902 \\
\hline & Minimum relative humidity & 63.00 & 1.12 & 11.25 & 78.33 & 51.5 & -0.75 & 0.449 \\
\hline & Maximum relative humidity & 83.78 & 0.824 & 6.218 & 93.07 & 74.29 & -1.037 & 0.00447 \\
\hline & Average relative humidity & 73.39 & 0.903 & 7.778 & 85.7 & 64.72 & -0.809 & 0.414 \\
\hline & Rainfall (mm) & 31.43 & 7.583 & 152.6 & 258.7 & 0 & 10.92 & 2.992 \\
\hline \multirow{14}{*}{ Kibaka } & Mealybug twig ${ }^{-1}$ & 77.13 & 12.73 & 104.4 & 324 & 3 & 1.153 & 1.394 \\
\hline & Mealybug leaf ${ }^{-1}$ & 49.6 & 5.313 & 67.75 & 136 & 5 & -0.0782 & 0.864 \\
\hline & Mealybug fruit ${ }^{-1}$ & 37.92 & 9.215 & 153.7 & 178 & 0 & 0.0132 & 1.267 \\
\hline & Percent parasitism_twig ${ }^{-1}$ & 5.514 & 0.442 & 50.71 & 13.17 & 1.78 & 0.108 & 0.699 \\
\hline & Percent parasitism_leaf ${ }^{-1}$ & 6.07 & 0.431 & 44.88 & 14.58 & 2.14 & 1.221 & 1.108 \\
\hline & Percent parasitism_fruit ${ }^{-1}$ & 2.62 & 0.494 & 119.3 & 10.81 & 0 & -0.312 & 0.884 \\
\hline & Predator abundance & 35.3 & 6.354 & 113.8 & 195 & 0 & 4.316 & 1.868 \\
\hline & Minimum temperature & 23.34 & 0.205 & 5.569 & 25.45 & 19.86 & 0.672 & -1.125 \\
\hline & Maximum temperature & 31.93 & 0.194 & 3.835 & 34.1 & 29.29 & -0.698 & -0.426 \\
\hline & Average temperature & 27.63 & 0.188 & 4.297 & 29.39 & 24.9 & -0.127 & -0.829 \\
\hline & Minimum relative humidity & 63.2 & 1.146 & 11.47 & 76.87 & 51.39 & -0.901 & 0.508 \\
\hline & Maximum relative humidity & 83.82 & 0.829 & 6.252 & 92.87 & 74.58 & -1.042 & 0.0000796 \\
\hline & Average relative humidity & 73.51 & 0.916 & 7.878 & 84.87 & 64.8 & -1 & 0.366 \\
\hline & Rainfall $(\mathrm{mm})$ & 31.42 & 7.677 & 154.5 & 259.2 & 0 & 10.51 & 2.986 \\
\hline
\end{tabular}

Notes: S.E: Standard error; CV: coefficient of variation.

The temporal distribution of $R$. iceryoides incidence, percent parasitism on the leaves, twigs and fruits in Kibaha and Dar es Salaam were positively right-skewed with low median values (Table 1). The kurtosis $(-0.0892)$ for $R$. iceryoides incidence on fruit in Dar es Salaam and 0.0782 for leaf in Kibaha (platykurtic distribution). The kurtosis value was -1.068 and -0.782 for percent parasitism on fruits and twigs, respectively, and -0.312 on fruit in Kibaha. The average weekly rainfall was skewed or incline to have a distinct peak near the mean, decline rather rapidly, i.e. kurtosis 10.51 in Kibaha and 10.92 in Dar es Salaam (leptokurtic distribution) (Table 1), which 
are values greater than the skewed threshold (Kurtosis 3). For $R$. iceryoides, we observed that there was increase in the average weekly temperature, and kurtosis of temperature increased the average number of $R$. iceryoides per sampling date. For Kibaha, the kurtosis of minimum, maximum and mean temperature anomalies were $0.672,-0.127$ and -0.698 , respectively, while that in Dar es Salaam were $1.192,-0.679$ and 0.222 , respectively. Table 1 also illustrate the relative skewness and kurtosis for percent parasitism by A. pseudococci and the predator variable during the study period.

Multiple regression of $R$. iceryoides infestation, percent parasitism and predators with weather variables

The results of the multiple linear regression on $R$. iceryoides population, percent parasitism, predators and selected weather parameters showed that the pest $R$. iceryoides population were significantly positively associated with average temperature on the leaves and twigs in Kibaha and Dar es Salaam (Table 2). Whereas it was significantly negatively related to rainfall on the twigs and leaves except on the fruits (Table 2) in both study sites. 


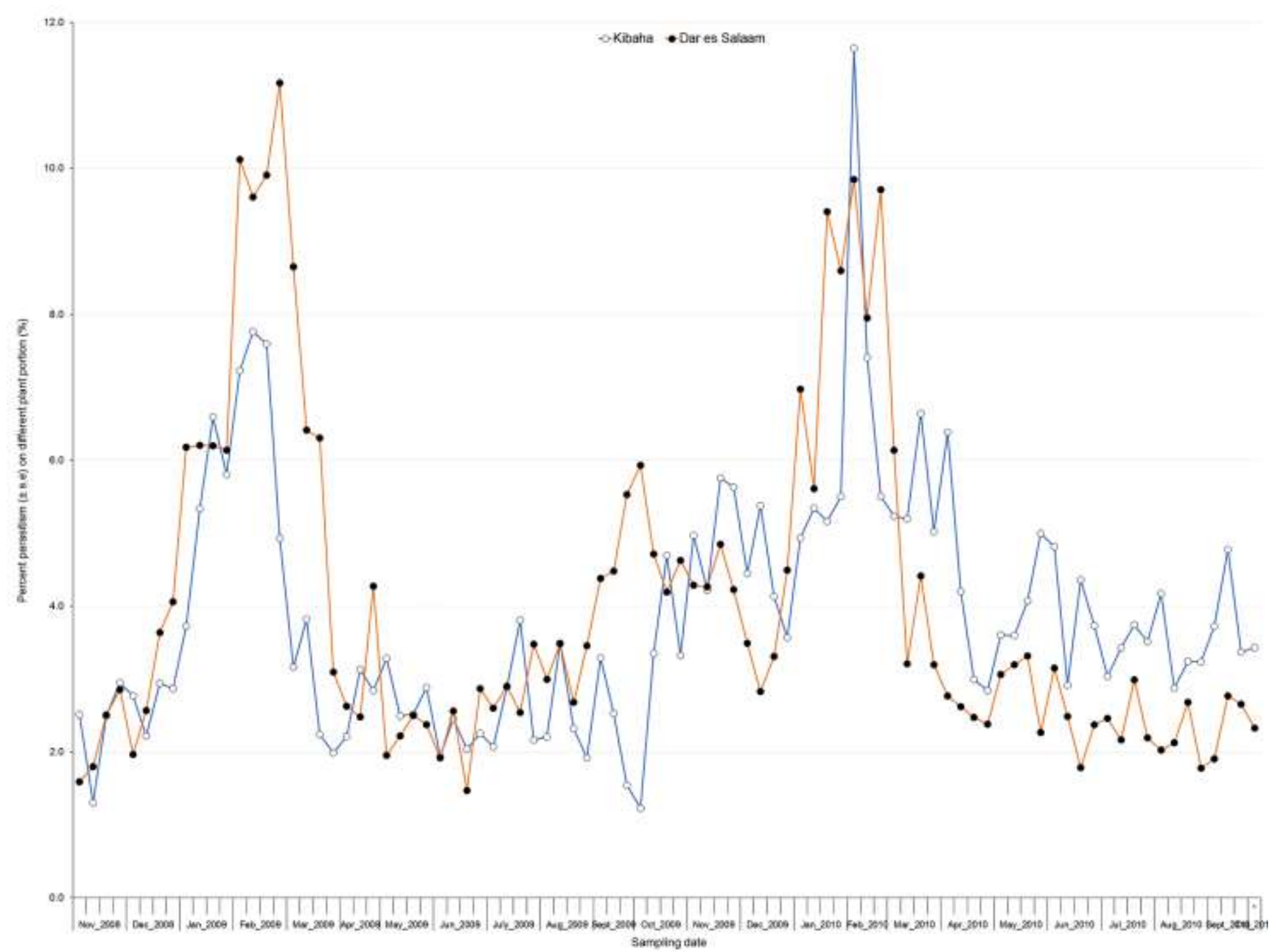

Figure 3. Seasonal variation of percentage parasitism of Rastrococcus iceryoides by Anagyrus pseudococci recorded in Kibaha and Dar es Salaam. 
Table 2: Multiple regression of Rastrococcus iceryoides infestation with various meteorological parameters in Kibaka and Dar-es-Salaam

\begin{tabular}{|c|c|c|c|c|c|c|}
\hline \multirow{3}{*}{ Parameter } & \multicolumn{6}{|c|}{ Kibaka } \\
\hline & \multicolumn{2}{|c|}{ Leaf } & \multicolumn{2}{|c|}{ Twig } & \multicolumn{2}{|c|}{ Fruit } \\
\hline & Slope & $\mathrm{R}^{2}$ & Slope & $\mathrm{R}^{2}$ & Slope & $\mathrm{R}^{2}$ \\
\hline Minimum relative humidity & $-0.03 \pm 0.02$ & $0.08 \mathrm{~ns}$ & $-0.05 \pm 0.02$ & $0.11^{*}$ & $-0.05 \pm 0.05$ & $0.03 \mathrm{~ns}$ \\
\hline Maximum relative humidity & $-04 \pm 0.023$ & $0.07 \mathrm{~ns}$ & $-0.07 \pm 0.01$ & $0.09 \mathrm{~ns}$ & $-0.15 \pm 0.06$ & $0.14 *$ \\
\hline Average relative humidity & $-0.04 \pm 0.02$ & $0.09 \mathrm{~ns}$ & $-0.07 \pm 0.03$ & $0.12 *$ & $-0.10 \pm 0.06$ & $0.07 \mathrm{~ns}$ \\
\hline Minimum Temperature & $0.29 \pm 0.08$ & $0.24 * *$ & $-0.32 \pm 0.13$ & $0.14^{*}$ & $0.60 \pm 0.24$ & $0.14 *$ \\
\hline Maximum Temperature & $0.31 \pm 0.09$ & $0.26^{* * *}$ & $0.35 \pm 0.14$ & $0.14^{*}$ & $0.42 \pm 0.27$ & $0.06 \mathrm{~ns}$ \\
\hline Average temperature & $0.34 \pm 0.09$ & $0.28 * *$ & $0.38 \pm 0.14$ & $0.16^{*}$ & $0.58 \pm 0.27$ & $0.11 *$ \\
\hline \multirow[t]{2}{*}{ Rainfall (mm) } & $-0.01 \pm 0.00$ & $0.34 * * *$ & $-0.01 \pm 0.00$ & $0.31 * * *$ & $-0.01 \pm 0.01$ & $0.07 \mathrm{~ns}$ \\
\hline & \multicolumn{6}{|c|}{ Dar-es-Salaam } \\
\hline Minimum relative humidity & $-0.02 \pm 0.02$ & $0.04 \mathrm{~ns}$ & $-0.03 \pm 0.02$ & $0.04 \mathrm{~ns}$ & $-0.06 \pm 0.04$ & $0.06 \mathrm{~ns}$ \\
\hline Maximum relative humidity & $-0.04 \pm 0.03$ & $0.06 \mathrm{~ns}$ & $-0.07 \pm 0.03$ & $0.12 *$ & $-0.14 \pm 0.05$ & $0.15^{*}$ \\
\hline Average relative humidity & $-0.04 \pm 0.02$ & $0.06 \mathrm{~ns}$ & $-0.05 \pm 0.03$ & $0.08 \mathrm{~ns}$ & $-0.12 \pm 0.05$ & $0.11 *$ \\
\hline Minimum Temperature & $0.40 \pm 0.09$ & $0.36^{* * *}$ & $0.43 \pm 0.11$ & $0.28 * *$ & $0.72 \pm 0.21$ & $0.23 * *$ \\
\hline Maximum Temperature & $0.34 \pm 0.11$ & $0.22 * *$ & $0.41 \pm 0.13$ & $0.21 * *$ & $0.59 \pm 0.25$ & $0.13 *$ \\
\hline Average temperature & $0.42 \pm 0.10$ & $0.32 * * *$ & $0.48 \pm 0.15$ & $0.28 * * *$ & $0.75 \pm 0.24$ & $0.25 * *$ \\
\hline Rainfall (mm) & $-0.01 \pm 0.00$ & $0.16^{*}$ & $-0.01 \pm 0.00$ & $0.17 * *$ & $-0.01 \pm 0.00$ & $0.09 \mathrm{~ns}$ \\
\hline
\end{tabular}

ns $=$ model not significant at $\alpha=5 \%, *$ model significant at $\alpha=5 \%, * *$ model significant at $\alpha=1 \%,{ }^{* * *}$ model significant at $\alpha=0.1 \%$

Average temperature was significant and positively associated with $R$. iceryoides parasitism rate on the twigs and fruits as well as on predator abundance in Kibaha, while in Dar es Salaam, a significant positive relationship was observed for parasitism rate on fruits and predator abundance (Table 3). As plotted against $R$. iceryoides versus predators, and $R$. iceryoides versus parasitism, the best-fit model for describing $R$. iceryoides incidence patterns was linear in both Kibaha and Dar es Salaam (Figure 4). The cumulative effect of predators on the population build-up of the pest $R$. iceryoides revealed that they had a significant effect to an extent of $52.5 \%\left(R^{2}=0.5245\right)$ and $47.5 \%\left(R^{2}=0.4748\right)$ in Kibaha and Dar es Salaam, respectively. The impact of the parasitoid on the $R$. iceryoides population was minimal with $13.4 \%\left(\mathrm{R}^{2}=0.1337\right)$ and $18.1 \%\left(\mathrm{R}^{2}=0.1813\right)$ in Kibaha and Dar es Salaam, respectively (Figure 4). 
Table 3: Multiple regression of percent parasitism and predator abundance with various meteorological parameters in Kibaka and Dar-es-Salaam

\begin{tabular}{|c|c|c|c|c|c|c|c|c|}
\hline \multirow{4}{*}{ Parameter } & \multicolumn{2}{|c|}{ Predator } & \multicolumn{6}{|c|}{ Percent parasitism } \\
\hline & \multicolumn{8}{|c|}{ Kibaka } \\
\hline & \multirow[b]{2}{*}{ Slope } & \multirow[b]{2}{*}{$\mathrm{R}^{2}$} & \multicolumn{2}{|c|}{ Leaf } & \multicolumn{2}{|c|}{ Twig } & \multicolumn{2}{|c|}{ Fruit } \\
\hline & & & Slope & $\overline{\mathrm{R}^{2}}$ & Slope & $\mathrm{R}^{2}$ & Slope & $\mathrm{R}^{2}$ \\
\hline \multirow{2}{*}{$\begin{array}{l}\text { Minimum relative humidity } \\
\text { Maximum relative humidity }\end{array}$} & $-0.03 \pm 0.03$ & $0.02 \mathrm{~ns}$ & $0.05 \pm 0.07$ & $0.01 \mathrm{~ns}$ & $-0.06 \pm 0.08$ & $0.03 \mathrm{~ns}$ & $-0.36 \pm 0.17$ & $0.15 *$ \\
\hline & $-0.08 \pm 0.04$ & $0.10 \mathrm{~ns}$ & $0.02 \pm 0.09$ & $0.00 \mathrm{~ns}$ & $-0.12 \pm 0.11$ & $0.03 \mathrm{~ns}$ & $-0.63 \pm 0.13$ & $0.24 * *$ \\
\hline Average relative humidity & $-0.05 \pm 0.03$ & $0.06 \mathrm{~ns}$ & $0.04 \pm 0.08$ & $0.01 \mathrm{~ns}$ & $-0.09 \pm 0.09$ & $0.02 \mathrm{~ns}$ & $-0.55 \pm 0.19$ & $0.21 * *$ \\
\hline \multirow{2}{*}{$\begin{array}{l}\text { Minimum Temperature } \\
\text { Maximum Temperature }\end{array}$} & $0.46 \pm 0.14$ & $0.22 * *$ & $0.65 \pm 0.38$ & $0.07 \mathrm{~ns}$ & $1.13 \pm 0.38$ & $0.17 * *$ & $1.98 \pm 0.78$ & $0.14 *$ \\
\hline & $0.36 \pm 0.16$ & $0.12 *$ & $0.51 \pm 0.41$ & $0.04 \mathrm{~ns}$ & $1.51 \pm 0.39$ & $0.28 * * *$ & $2.23 \pm 0.82$ & $0.16 *$ \\
\hline \multirow{3}{*}{$\begin{array}{l}\text { Average temperature } \\
\text { Rainfall (mm) }\end{array}$} & $0.47 \pm 0.16$ & $0.19^{*}$ & $0.66 \pm 0.42$ & $0.06 \mathrm{~ns}$ & $1.48 \pm 0.42$ & $0.25 * * *$ & $2.37 \pm 0.85$ & $0.17 * *$ \\
\hline & $-0.01 \pm 0.00$ & $0.05 \mathrm{~ns}$ & $-4 \times 10^{-3} \pm 0.01$ & $0.00 \mathrm{~ns}$ & $-0.02 \pm 0.01$ & $0.05 \mathrm{~ns}$ & $-0.04 \pm 0.02$ & $0.07 \mathrm{~ns}$ \\
\hline & \multicolumn{8}{|c|}{ Dar-es-Salaam } \\
\hline \multirow{2}{*}{$\begin{array}{l}\text { Minimum relative humidity } \\
\text { Maximum relative humidity }\end{array}$} & $0.002 \pm 0.02$ & $0.00 \mathrm{~ns}$ & $-0.13 \pm 0.07$ & $0.09 \mathrm{~ns}$ & $-0.12 \pm 0.08$ & $0.04 \mathrm{~ns}$ & $-0.27 \pm 0.16$ & $0.07 \mathrm{~ns}$ \\
\hline & $-0.02 \pm 0.03$ & $0.01 \mathrm{~ns}$ & $-0.13 \pm 0.09$ & $0.05 \mathrm{~ns}$ & $-0.09 \pm 0.11$ & $0.02 \mathrm{~ns}$ & $-0.47 \pm 0.21$ & $0.11 *$ \\
\hline Average relative humidity & $-0.01 \pm 0.03$ & $0.00 \mathrm{~ns}$ & $-0.15 \pm 0.08$ & $0.08 \mathrm{~ns}$ & $-0.12 \pm 0.10$ & $0.03 \mathrm{~ns}$ & $-0.41 \pm 0.19$ & $0.10 *$ \\
\hline Minimum Temperature & $0.43 \pm 0.10$ & $0.33 * * *$ & $0.53 \pm 0.39$ & $0.05 \mathrm{~ns}$ & $0.73 \pm 0.46$ & $0.06 \mathrm{~ns}$ & $2.78 \pm 0.83$ & $0.23 * *$ \\
\hline Maximum Temperature & $0.29 \pm 0.12$ & $0.13 *$ & $0.48 \pm 0.43$ & $0.03 \mathrm{~ns}$ & $1.17 \pm 0.49$ & $0.13 *$ & $2.65 \pm 0.94$ & $0.18 * *$ \\
\hline Average temperature & $0.42 \pm 0.12$ & $0.25 * * *$ & $0.58 \pm 0.43$ & $0.05 \mathrm{~ns}$ & $1.05 \pm 0.50$ & $0.10 \mathrm{~ns}$ & $3.08 \pm 0.92$ & $0.23 * *$ \\
\hline Rainfall (mm) & $-.001 \pm 0.00$ & $0.01 \mathrm{~ns}$ & $-0.027 \pm 0.01$ & $0.17 * *$ & $-0.02 \pm 0.01$ & $0.09 \mathrm{~ns}$ & $-0.046 \pm 0.02$ & $0.09 \mathrm{~ns}$ \\
\hline
\end{tabular}



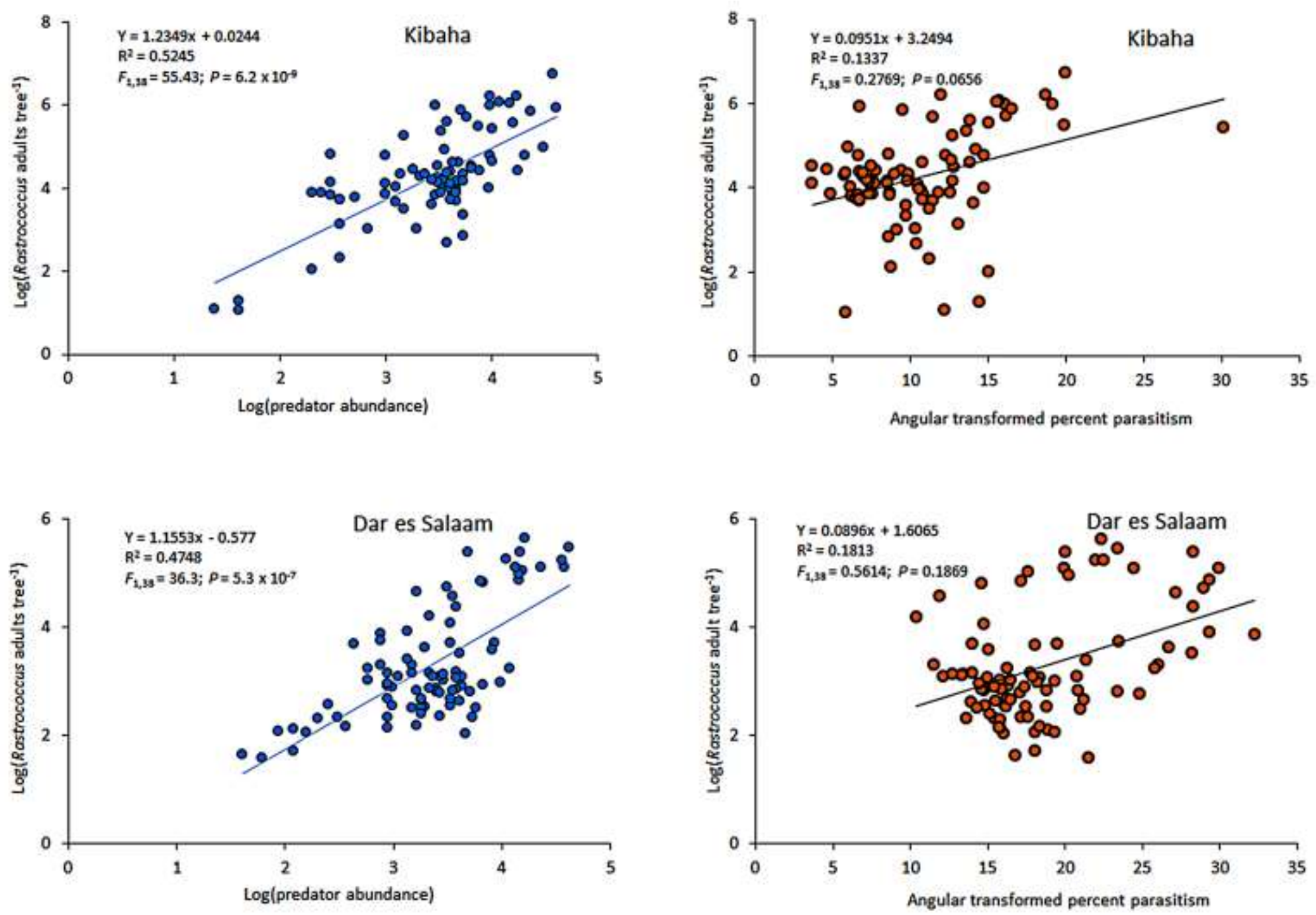

Figure 4. Linear regression relationship of Rastrococcus iceryoides weekly abundance vs percentage parasitism and predator abundance in Kibaha and Dar es Salaam. 
Autocorrelation between weather variables, $R$. iceryoides abundance, percent parasitism and predators

The autocorrelation functions, which is the correlations between two values of the same variable at times $x_{i}$ and $x_{i+h}$, for $R$. iceryoides, percent parasitism, temperature, $\mathrm{RH}$, rainfall and predators were cyclical (Figure 5). With increased time lag, the ACF coefficients became interchangeably positive and negative, sometimes approaching zero at time lag 4 or above for $R$. iceryoides abundance, percent parasitism, temperature, predator abundance and rainfall amount. The ACF coefficient values were higher for $R$. iceryoides, percent parasitism and temperature with significantly different values (i.e., points above the dashed lines). The percent parasitism in Kibaha, RH, rainfall and predator abundance fluctuated at low and constant ACF coefficient values (i.e., points below the dashed lines). During the computing process, each variable was found to be autocorrelated within time lags of $4-7$ (months), established on the time lag when ACF coefficients were zero. 

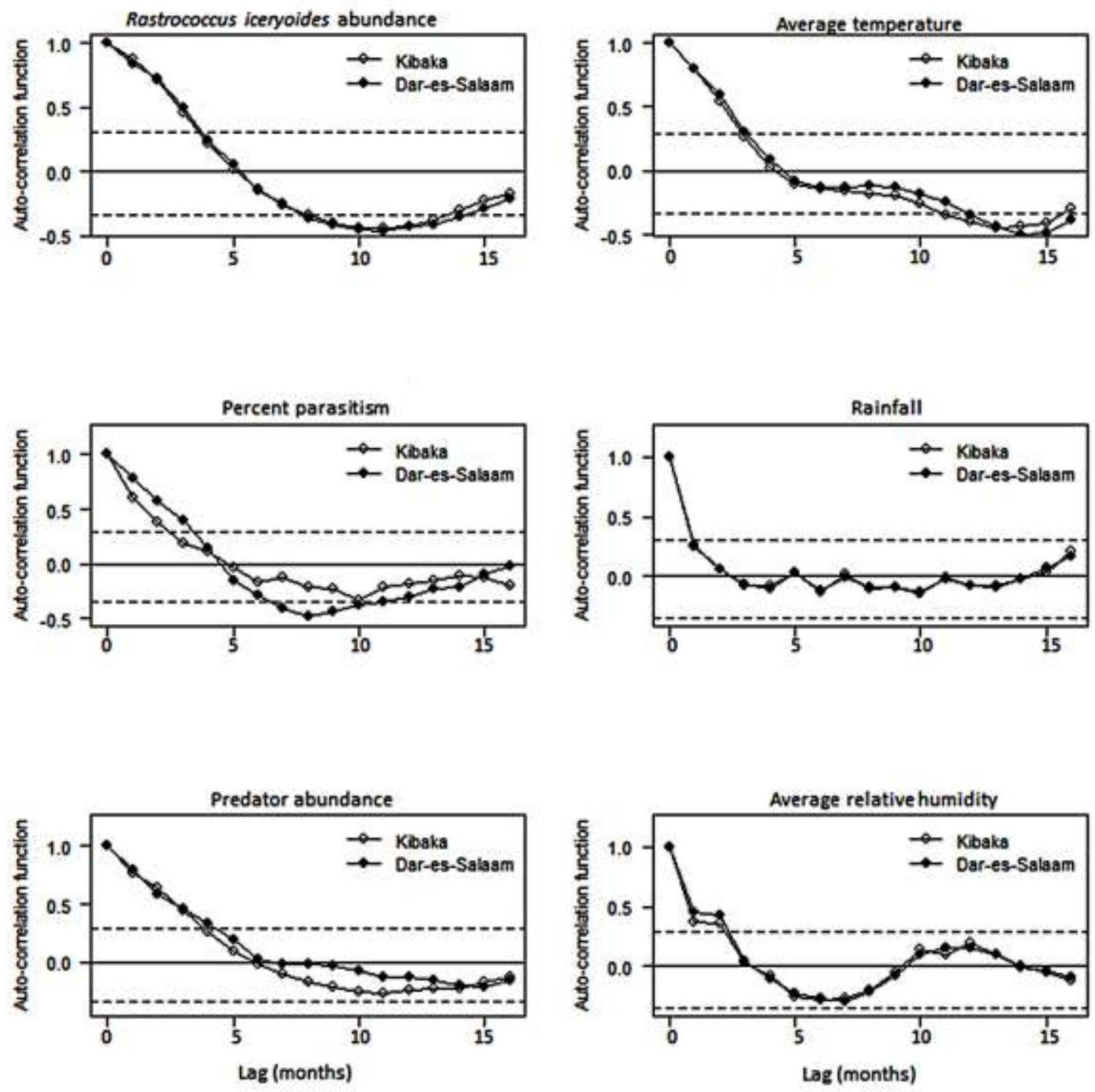

Figure 5. Autocorrelation functions (ACF coefficients) for Rastrococcus iceryoides, percent parasitism, predator abundance, air temperature rainfall and relative humidity. The dashed lines represent significant levels; any coefficient above the dashed line is significantly different from 0 at $\mathrm{P}<0.05$. 
A
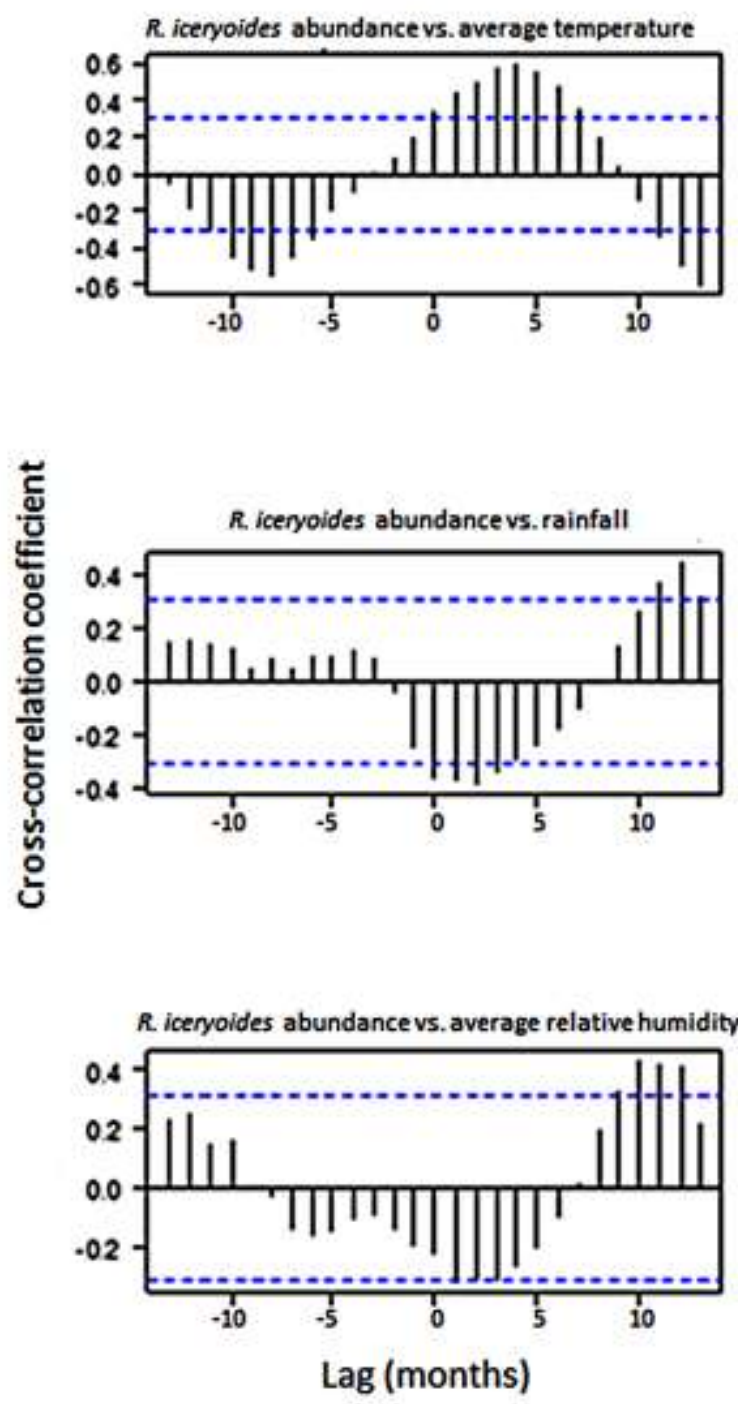

B
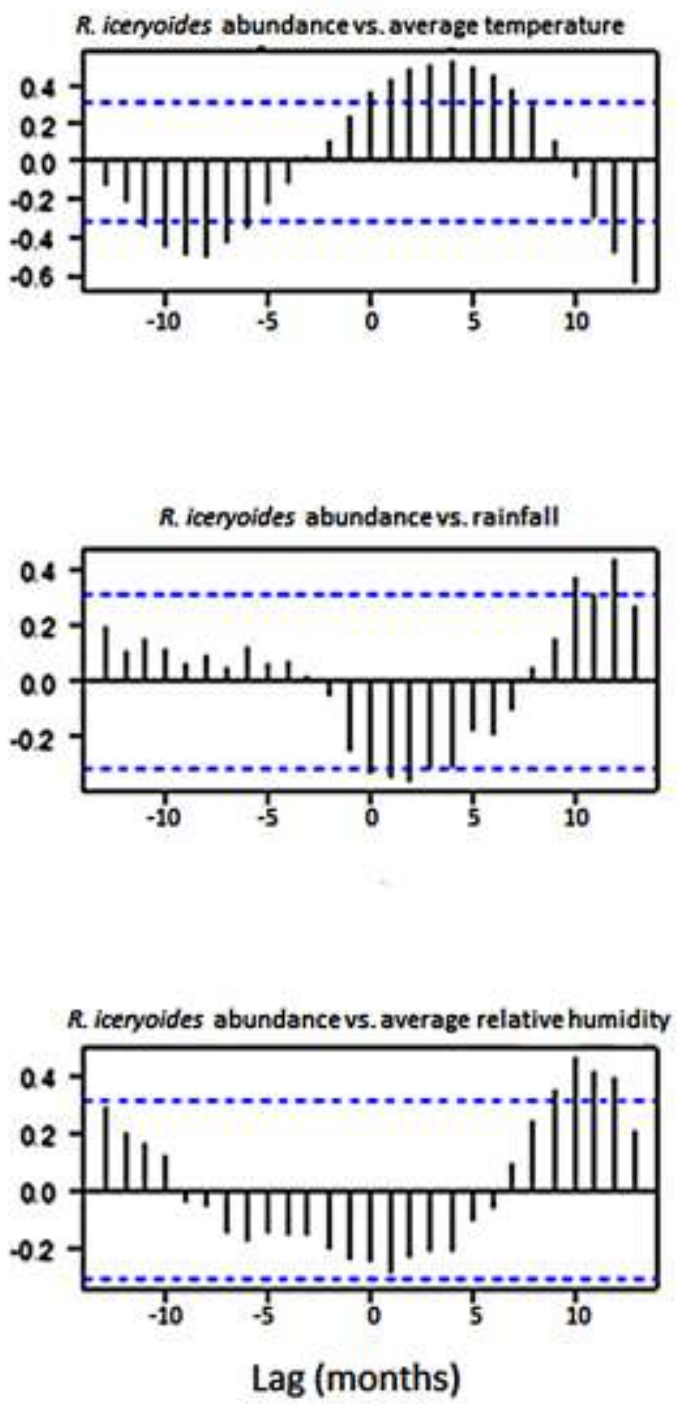

Figure 6. Cross-correlation functions (CCF coefficients) for Rastrococcus iceryoides vs air temperature, rainfall and relative humidity in Kibaha (A) and Dar es Salaam (B). The dashed lines represent the $95 \%$ confidence limit for the cross-correlation functions.

\section{Cross-correlation of adult $R$. iceryoides with weather, percent parasitism and predators}

There was significant cross-correlation between average temperature with mean abundance of $R$. iceryoides per month in Kibaha (Figure 6A) and Dar es Salaam (Figure 6B). Mean $R$. iceryoides incidence per month increased positively after a lag of $1-7$ months following an 
increase in average temperature in both location (Figure 6A \& 6B). In Kibaha mean $R$. iceryoides incidence per month was significantly negatively cross-correlated with monthly rainfall after a lag of $1-3$ months and positively correlated with increasing rainfall after a lag of $10-11$ months. But in Dar es Salaam, $R$. iceryoides incidence per month was positively correlated with increasing rainfall after a lag of 10 and 11 months, respectively (Figure 6B). Increases in mean $R$. iceryoides per month were positively significantly correlated with average relative humidity in Kibaha at a lag of $10-12$ months (Figure 6A), while in Dar es Salaam it was positively correlated at a lag of $9-12$ months.

There was significant negative cross-correlation between average temperature and average percent parasitism of $R$. iceryoides per month in both sites (Figure 7A \& 7B). Percent parasitism of $R$. iceryoides per month was observed to increase positively after a lag of -1 to 4 months following an increase in average temperature in Kibaha (Figure 7A), while that in Dar es Salaam at a lag of 1 to 4 months (Figure 7B). In Dar es Salaam, mean percentage parasitism of $R$. iceryoides per month was not significantly cross-correlated with monthly rainfall, but in Kibaha, $R$. iceryoides parasitism per month was positively correlated with increasing rainfall after a lag of 7 and 8 months (Figure 7A), but negatively correlated after a lag of minus (-) 1 month (Figure 7B). Increases in mean parasitism of $R$. iceryoides per month was positively correlated with increasing average relative humidity after a lag of $6-9$ months and $6-7$ months in Kibaha and Dar es Salaam, respectively (Figure 7A \& 7B). 
A

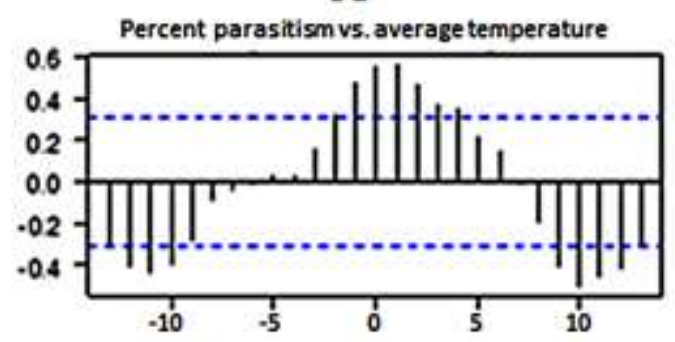

동

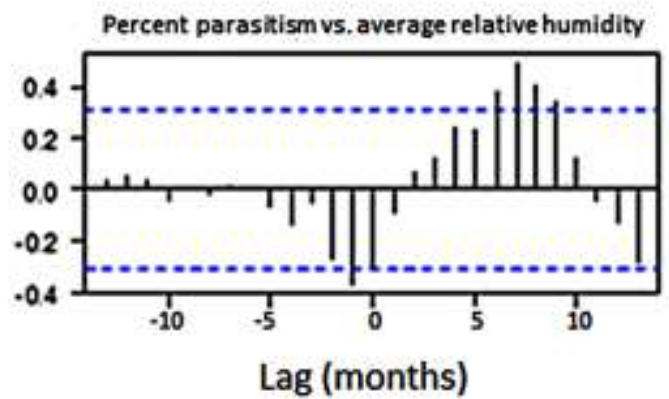

B
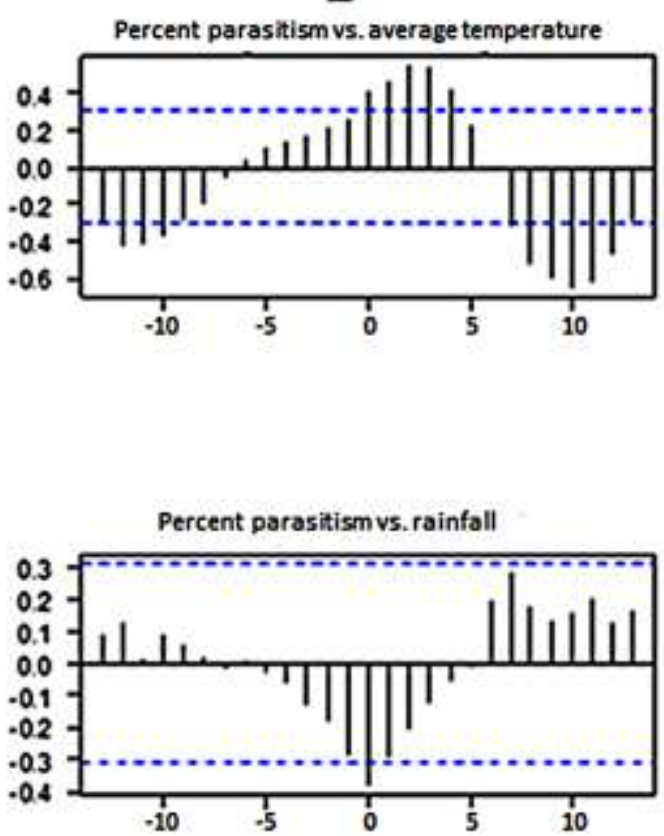

Figure 7. Cross-correlation functions (CCF coefficients) for percent parasitism of Rastrococcus iceryoides by Anagyrus pseudococci vs air temperature, rainfall and relative humidity in Kibaha (A) and Dar es Salaam (B). The dashed lines represent the $95 \%$ confidence limit for the cross-correlation functions.

No significant cross-correlation between average relative humidity and rainfall with mean predator abundance per month was recorded in Dar es Salaam (Figure 8A and 8B). Mean predators collected per month increased positively after a lag of $2-5$ months following an increase in average temperature in Kibaha. But in Kibaha and Dar es Salaam, predator abundance was 
negatively correlated with mean monthly average temperatures at a lag of $12-13$ months (Figure $8 \mathrm{~A}$ and $8 \mathrm{~B}$ ). In Kibaha, mean predator trapped per month was only significantly positively crosscorrelated with monthly rainfall and mean relative humidity after a lag of 13 and 11, respectively (Figure 8A).

A
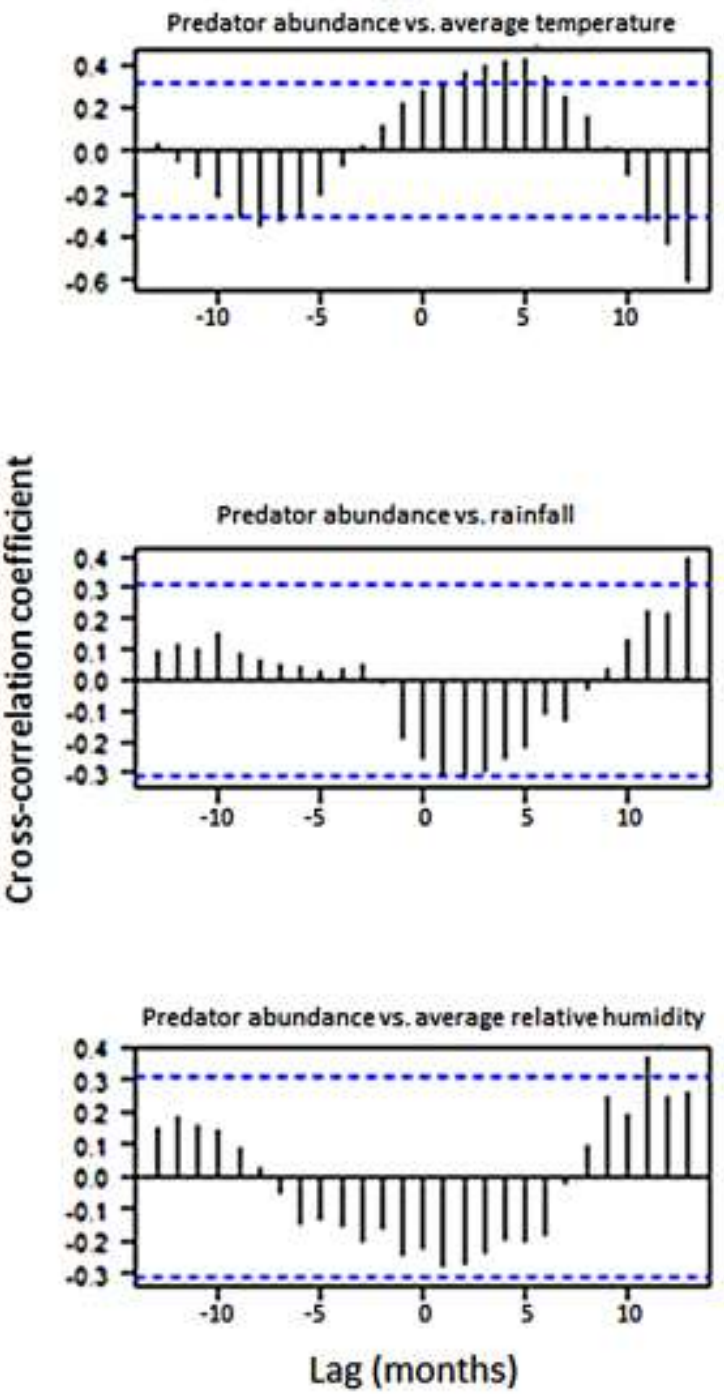

B
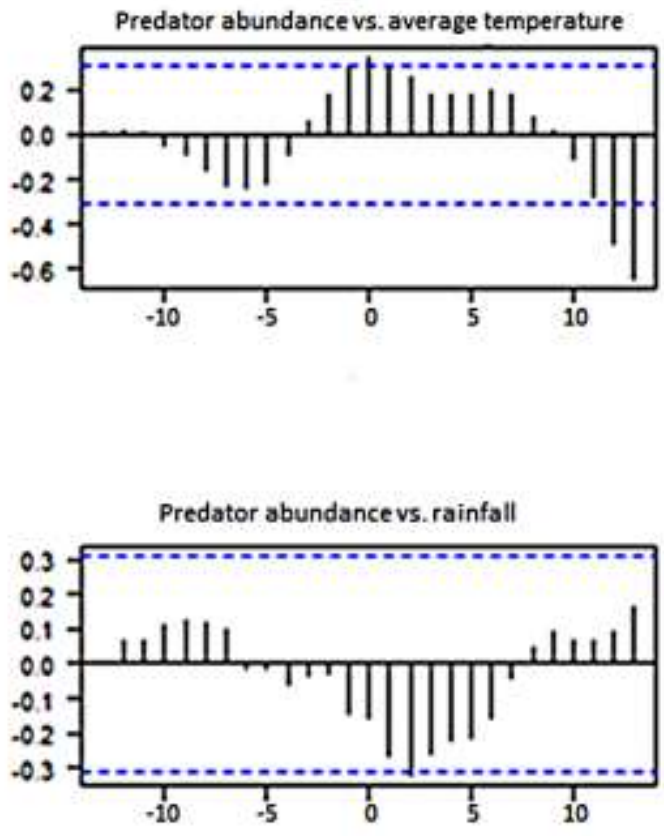

Figure 8. Cross-correlation functions (CCF coefficients) for predator abundance vs air temperature, rainfall and relative humidity in Kibaha (A) and Dar es Salaam (B). The dashed lines represent the $95 \%$ confidence limit for the cross-correlation functions.

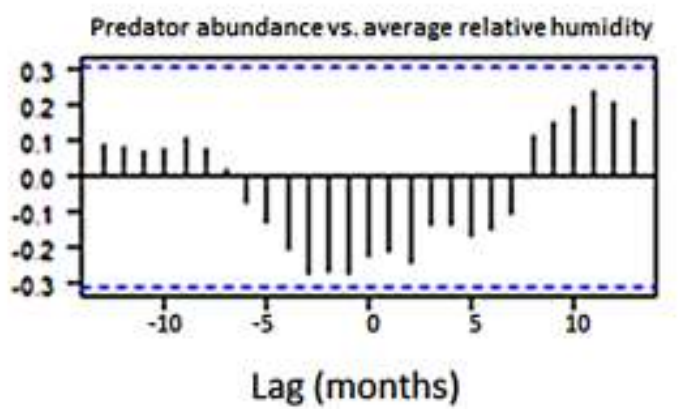


The cross-correlation functions $\gamma_{x y}(h)$ (CCF coefficients) varied between -0.605 and 0.589 for $R$. iceryoides $(y)$ versus temperature $(x),-0.383$ and 0.446 for $R$. iceryoides $(x)$ versus rainfall (y) and -0.317 and 0.427 for $R$. iceryoides versus rainfall in Kibaha. In Dar es Salaam, the crosscorrelation functions varied between -0.637 and 0.526 for $R$. iceryoides (y) versus temperature (x), -0.358 and 0.436 for $R$. iceryoides (x) versus rainfall (y) and -0.286 and 0.463 for $R$. iceryoides versus rainfall. The cross-correlation functions varied between -0.501 and 0.561 for percent parasitism (y) versus temperature $(\mathrm{x}),-0.363$ and 0.507 for percent parasitism (x) versus rainfall (y) and -0.367 and 0.487 for percent parasitism $(y)$ versus $\mathrm{RH}(x)$ in Kibaha. In Dar es Salaam, the cross-correlation functions varied from -0.653 to 0.545 for percent parasitism (y) versus temperature $(\mathrm{x}),-0.381$ and 0.285 for percent parasitism $(x)$ versus rainfall $(y)$ and -0.293 and 0.417 for percent parasitism $(y)$ versus $\mathrm{RH}(x)$. The CCF coefficients exhibited a cyclic, positive response association between $R$. iceryoides abundance with percent parasitism, predators and all the climatic variables.

\section{Discussion}

This study defines the influence of meteorological factors on $R$. iceryoides incidence and its associated biocontrol agents using time series analysis of monthly temperature (minimum, maximum and average), $\mathrm{RH}$ (minimum, maximum and average) and total rainfall from 2008 to 2010 in two geographically distinct areas of Tanzania. Although temperature, rainfall and relative humidity play a key role in $R$. iceryoides developmental life cycle, these factors have never been collectively used as an index to allow the prediction of its outbreaks and that of its associated natural enemies in a mango agro-ecosystem. There were clear and distinct seasonal peaks of activities of $R$. iceryoides and its associated natural enemies with high population outbreaks closely 
associated with the mango fruiting season. The positive association between $R$. iceryoides, minimum, mean and maximum temperature variables over the study period revealed that $R$. iceryoides populations increased with increases in temperature. There was a negative relationship between $R$. iceryoides incidence and climatic factors like relative humidity and rainfall, which played a significant role in reducing the populations of $R$. iceryoides throughout the study period. Rainfall and R. iceryoides infestation were highly skewed [i.e. kurtosis 10.51 in Kibaha and 10.92 in Dar es Salaam, which are values higher than the skewed threshold with Kurtosis values $>3$ (Table 1)].

The observed linear increase of $R$. iceryoides abundance with the increases in air temperature in the orchards strongly agrees with reports presented by several authors that increase in temperature is important to temperature-driven insect pests (Williams \& Liebhold, 2002; Peacock et al., 2006; Herrera et al., 2005). Many authors have confirmed that insect larvae or nymphs and adults need sufficiently warmer temperatures for adequate growth and survival (Williams \& Liebhold, 2002; Peacock et al., 2006; Herrera et al., 2005). Both female and male mealybug nymphal instars growth has been demonstrated to be consistently fast at optimum and maximum temperature thresholds of 28 to $32^{\circ} \mathrm{C}$ (Amarasekare et al., 2008). Contrarily, mealybug nymphal instars held at cooler temperatures regime have been reported to have greater mobility and mortality than those held at warmer daily temperatures of 26 to $37^{\circ} \mathrm{C}$ (Bale, 1989; 1991; Niesenbaum \& Kluger, 2006). Similarly, Coulson and Bale (1996) further confirmed that continual low temperatures in comparison to changing thermal treatments are comparatively more detrimental to insect species. Optimal temperature thresholds for $R$. iceryoides outbreaks ranged between 25 to $29^{\circ} \mathrm{C}$ with 6 to 8 generations produced per year, which corroborates the findings of Chong et al. (2008), who also reported a similar range for rapid proliferation of papaya mealybug 
Paracoccus marginatus Williams and Granara de Willink (Hemiptera: Pseudococcidae). In an earlier study, the author found that $P$. marginatus had the highest fecundity at $28.7^{\circ} \mathrm{C}$ with $65 \pm$ 2\% RH (Chong et al., 2003), which is comparable to our observation in the field. Thus, the ability of $R$. iceryoides to complete develop, sufficiently survive, and successfully reproduce between $19.83^{\circ} \mathrm{C}$ and $34^{\circ} \mathrm{C}$ proposes that $R$. iceryoides has the ability to establish and colonize areas within that temperature range. Our findings agree with that of Le Rü et al. (1991) who reported that Phenacoccus manihoti Matile-Ferrero (Homoptera: Pseudococcidae) populations increased by ten-fold during the drier period of the year compared to the wet season.

Several authors have tried to explain the mechanisms for how weather conditions influence developmental and survival patterns, and the potential of high temperature to promote pest outbreaks. For example, some authors have attributed the increase of mealybug populations in the dry season to fluctuations in the amounts of secondary compounds which induces changes in host plant physiology (leading to high susceptibility to infestation) that favour faster development and high reproduction under water stress (Fabres \& Le Rü, 1988; Gutierrez et al., 1993; Calatayud et al., 1994; Koricheva et al., 1998; Lunderstadt, 1998; Calatayud et al., 2000; Calatayud et al., 2002; Shrewsbury et al., 2004). Generally, plant-sucking insect outbreaks in the warmer seasons are very common due to the availability healthier food sources and highly improved nutritional quality in the host plant tissues (Mattson \& Haack, 1987) such as nitrate, betaine, sugars and amino acids (praline), which would accrue to higher levels than usual in plant tissues during warmer temperatures (Mattson \& Haack, 1987; Li et al., 2006; Pires et al., 2000; Williams \& Liebhold, 2002).

Rainfall and relative humidity were significantly and negatively associated with $R$. iceryoides outbreaks, which is consistent with the results reported by Suresh and Kavitha (2008) 
in India. Thus, in the current studies rainfall remains one of the major predictive indices directly involved in the sharp decline of $R$. iceryoides population in the field. Similarly, Suresh and Kavitha (2008) also observed that for every unit increase in rainfall and relative humidity, there was a $0.05-$ unit population reduction in the $R$. iceryoides population in India. This implies that heavy rains could be partly responsible for washing off $R$. iceryoides from their host plants to the soil surface, which will lead to considerable mortality and decline in their populations. Grant and Villani (2003) demonstrated that at high humidity (97.5\%), Beauveria bassiana fungal species were to a greater degree more efficient in infecting and killing host insect pests than at low humidity levels (75$80 \%$ ), which might indicate their possible role leading to $R$. iceryoides under field conditions. Similar findings on the influence of rainfall have been reported for other mealybug species such as Maconellicoccus hirsutus (Green) (Mukherjee, 1919; Sriharan et al., 1979; Shree \& Boraiah, 1988), Phenacoccus solenopsis Tinsley (Suresh \& Kavitha, 2008; Dhawan et al., 2009) and a congeneric pest $R$. invadens in West Africa (Pitan, 2000; Boavida \& Neuenschwander, 1995). Besides the negative influence of rainfall on $R$. iceryoides outbreaks, rainfall has also been shown to promote vegetative growth by influencing the nutritional quality in plant tissues, which is likely to encourage new colonization sites for subsequent mealybug generations (Singh, 1968; Whiley, 1993; Boavida \& Neuenschwander, 1995). In present studies, large populations of young nymphal instars of $R$. iceryoides were observed to move from older leaves to new young shoots as the leafflushing patterns of the mango plants changed, which is in accordance with the findings by Boavida and Neuenschwander (1995).

Beside temperature, rainfall and relative humidity, additional factors like availability of natural enemies (parasitoids and predators) can also contribute to the population fluctuations of $R$. iceryoides. The parasitoid Anagyrus pseudococci (Girault) and predator populations were well 
synchronized (density dependant manner) with that of the host, $R$. iceryoides. The following predators: H. bigeminata, C. renipustulatus, C. nigrita; S. lemolea and C. perspicax exhibited a strong and positive association with $R$. iceryoides (data not shown). This is in agreement with other findings, where the impact of predators on mealybug and other insect species (aphids) have frequently been reported (Singh et al., 2000; Kulkarni \& Patel, 2001; Mani \& Krishnamoorthy, 2007c). Although, A. pseudococci population was observed to increase during the dry season, their impact on $R$. iceryoides was negligible, which might be attributed to low co-evolutionary relationships between both species. The low performance of $A$. pseudococci to reduce outbreak populations of $R$. iceryoides can also be attributed to the presence of more than 18 species of hyperparasitoids recorded during the study period (Tanga, 2012). Chartocerus conjugalis (Mercet) of the family Signiphoridae (Hymenoptera: Chalcidoidea) was the most dominant species representing $>80 \%$ of the total number hyperparasitoids recorded (Tanga 2012). Hyperparasitoids have also been reported to significantly impact population and community patterns of many primary parasitoids, sufficient enough to interrupt biocontrol activities of the host (Holler et al., 1993; Van Nouhuys \& Hanski 2000; Morris et al., 2001; Van Veen et al., 2001).

Based on the findings from this study, the autocorrelation and cross-correlation time lag ranges can be used to determine optimum timing of eco-friendly strategies including biopesticides and biorational applications or augmentative releases of resident natural enemies or imported biocontrol agents against $R$. iceryoides taking into consideration the ambient temperature, relative humidity and rainfall patterns (Irshad, 1999; Shonouda et al., 2008; Duraimurugan \& Regupathy, 2005). Our results recommend that the optimum timing for the application of control against $R$. iceryoides would be in December when population starts building up until January - February, which is the time lag for outbreaks with warmer temperature and low rainfall. The present results 
have revealed that the high incidence of $R$. iceryoides, which occurs during the low raining period presents an opportunity for biopesticides and biorational applications for mealybug control, especially during the drier periods (December - February). Thus, the frequent outbreaks of mealybug pests ( $R$. iceryoides and $P$. marginatus) in Tanzania has motivated many neighbouring countries, including Kenya to begin monitoring populations along the borders (Macharia et al., 2017).

Our findings would serve as an early warning signal of $R$. iceryoides outbreak, before respective population sizes of the pest reach an economic threshold. Keeping these facts in mind, current investigation was conducted to develop an effective and economical strategy for managing the invasive mealybug pest. The significant gap or delays observed from one seasonal outbreak of $R$. iceryoides to the other, allows ample time for phytosanitary extension workers to introduce active mealybug control campaigns that combines different integrated pest management options, including the traditional pruning of heavily infested plant parts when the pest is most exposed. We also present a snapshot of the seasonal dynamics of $R$. iceryoides and its associated biocontrol agents, which allow for targeted biological control decisions in choosing the time, place and number of augmentative releases of the well-known primary parasitic wasps, A. pseudococci each year to outperform its host, $R$. iceryoides in different agro-ecosystems. Thus, regular update of this model through additional monitoring and surveillance activities is critical to produce current data, including multiple variables important to predicting pest outbreak risks in different regions and prospects of integrated pest management. 


\section{Acknowledgments}

This study was supported by the German Academic Exchange Service (DAAD) through the African Regional Postgraduate Program in Insect Science (ARPPIS). The authors gratefully thank

Peterson Nderitu for technical assistance. We remain indebted to the authorities of the National Biological Control Programme (NBCP), Kibaha, for their frank collaboration. Financial support from major organizations and agencies is greatly acknowledged: International Atomic Energy Agency (IAEA); Swedish International Development Cooperation Agency (Sida); the Swiss Agency for Development and Cooperation (SDC); UK Aid from the UK Government; Federal Ministry for Economic Cooperation and Development (BMZ), Germany and the Kenyan Governments. The views expressed herein do not necessarily reflect the official opinion of the donors.

\section{Conflict of interest statement}

No potential conflict of interest was reported by the authors.

\section{Author Contributions}

Conceptualization: CMT SAM ES.

Data curation: CMT SE SAM GP DS.

Formal analysis: DS CMT.

Funding acquisition: SE SAM.

Investigation: CMT SE SAM GP.

Methodology: CMT SE DS SAM GP.

Writing - original draft: CMT.

Writing - review \& editing: CMT DS SE SAM GP. 


\section{References}

Allen, E. K., Muegge, M. A., Wilson, L. T., \& Naranjo, S. E. (2008). Evaluation of sampling methods and development of sample plans for estimating predator densities in cotton. Journal of Economic Entomology, 101(4): 1501 - 1509.

Amarasekare, K. G., Chong, J-H., Epsky, N. D., \& Mannion, C.M. (2008). Effect of temperature on the life history of the mealybug Paracoccus marginatus (Hemiptera: Pseudococcidae). Journal of Economic Entomology, 101(6): 1798-804.

Arif, M. J., Gogi, M. D., Mirza, M., Zia, K. \& Hafeez, F. (2006). Impacts of plant spacing and abiotic factors on population dynamics of sucking insect pests of cotton. Pakistan Journal of Biological Sciences, 9: 1364-1369.

Bale, J. S. (1989). Cold hardiness and overwintering in insects. Agricultural Zoology Reviews, 3: 157-192.

Bale, J. S. (1991). Implications of cold hardiness for pest management. In Lee Jr. R. E. Deelinger, D.L. (eds). Insects at low temperature. Chapman and Hall, London, 461- 498.

Bergant, K., Trdan, S., Nidarcic, D., Crepinsek, Z., \& Kajfez-Bogataj, L. (2005). Impact of climate change on development dynamics of Thrips tabaci (Thysanoptera: Thripidae): can it be quantified? Physiological Ecology, 34: 755-766.

Blumberg, D., \& Van Driesche, R. G. (2001). Encapsulation rates of three encyrtid parasitoids by three mealybug species (Homoptera: Pseudococcidae) found commonly as pests in commercial greenhouses. Biological Control, 22: 191-199.

Boavida, C., \& Neuenschwander, P. (1995). Population dynamics and life tables of the mango mealybug, Rastrococcus invadens Williams, and its introduced natural enemy Gyranusoidea tebygi Noyes in Benin. Biocontrol Science and Technology, 5: 489-508.

Bokonon-Ganta, A. H., \& Neuenschwander P. (1995). Impact of the biological control agent Gyranusoidea tebygi Noyes (Hymenoptera: Encyrtidae) on the mango mealybug, Rastrococcus invadens Williams (Homoptera: Pseudococcidae), in Benin. Biocontrol Science and Technology, 5: 95-107.

CABI. 2000. Crop protection compendium. Global module, 2nd edition. CABI Publishing, Wallingford, UK.

Calatayud, P. A., Duchon, S., \& Amaze, T. L. (2000). Estimation of carbon and nitrogen modification during water deficiency in leaves of cassava, Manihot esculenta Crantz. In: Proceedings of the IV ${ }^{\text {th }}$ International Scientific Meeting of Cassava Biotechnology Network, Carvalho L.J.C.B., Thro A.M. \& A.D. Vilarinhos (eds), November 03-07, 1998, Salavador, Bahia, Brazil, p. 288-298.

Calatayud, P. A., Polania, M. A., Seligmann, C. D., \& Bellotti, A. C. (2002). Influence of waterstressed cassava on Phenacoccus herreni and three associated parasitoids. Entomologia experimentalis et applicate, 102: 163-175.

Calatayud, P.A., Rahbe, Y., Delobel, B., Khuonghuu, F., Tertuliano, M., \& Leru, B. (1994). Influence of secondary compounds in the phloem sap of cassava on expression of antibiosis 
towards the mealybug Phenacoccus manihoti. Entomologia Experimentalis et Applicata, 72: $47-57$.

Chaudhari, G.B., Bharpoda, T.M., Patel, J.J., Patel, K.I. \& Patel, J.R. (1999). Effect of weather on activity of cotton bollworms in middle Gujarat. Journal of Agrometeorology, 1: 137-142.

Chong, J-H, Oetting, R.D. \& Van Iersel, M.W. (2003). Temperature Effects on the Development, Survival, and Reproduction of the Madeira Mealybug, Phenacoccus madeirensis Green (Hemiptera: Pseudococcidae), on Chrysanthemum. Annals of the Entomological Society of America, 96 (4): 539-543.

Chong, J-H, Roda, A. L., \& Mannion, C. M., (2008). Life History of the Mealybug, Maconellicoccus hirsutus (Hemiptera: Pseudococcidae), at Constant Temperatures. Environmental Entomology, 37(2): 323-332.

Coulson, S. J., \& Bale, J. S. (1996). Supercooling and survival of beach leaf mining weevil Rhynchacus fogi L. Journal of Insect Physiology, 42: 617-623.

DeBach, P. (1949) Population Studies of the Long-Tailed Mealybug and Its Natural Enemies on Citrus Trees in Southern California. Ecology, 30(1): 14-25.

Derzelle, S., Ngo, S., Turlin, E., Duchaud, E., Namane, A., Kunst, F., Danchin, A., Bertin, P., \& Charles, J. F. (2004). AstR-AstS, a new two-component signal transduction system, mediates swarming, adaptation to stationary phase and phenotypic variation in Photorhabdus luminescens. Journal of the Society for General Microbiology, 150: 897-910.

Dhawan, A. K., Kamaldeep, S. A., \& Sarika, S. (2009). Distribution of mealybug, Phenacoccus solenopsis Tinsley in cotton with relation to weather factors in South-Western districts of Punjab. Journal of Entomological Research, 33(1): 59-63.

Dicke, M., Van Baarlen, P., Wessels, R., \& Dijkman, H. (1993). Herbivory induces systemic production of plant volatiles that attract predators of the herbivore: extraction of endogenous elicitor. Journal of Chemical Ecology, 19(3): 581-600.

Duraimurugan, P. \& Regupathy, A. (2005). Mitigation of insecticide resistance in Helicoverpa armigera (Hubner) (Lepidoptera: Noctuidae) by conjunctive use of trap crops, neem and Trichogramma chilonis Ishii in cotton. International Journal of Zoological research, 1: 53 58.

EON (2001) Encyclopedia of the Nations: Tanzania-Climate. http://www.nationsencyclopedia.com/Africa/Tanzania-CLIMATE.html

Fabres, G. \& Le Rü, B. (1988). Plant-insect relationships studies to improve cassava mealybug regulation methods. Proceedings of the Seventh Symposium of The International Society for Tropical Root Crops organized by INRA, 1-6 July 1985, Gosier Guadeloupe, Editions INRA, p. 563-577.

Garcia, A., Gonzalez, D., \& Leigh, T. F. (1982). Three methods for sampling arthropod numbers on California cotton. Environmental Entomology, 11: 565 - 572.

Godfray, H. C. J. (1994). Parasitoid: Behavioural and evolutionary ecology. Princeton, N.J: Princeton University Press. 
Grant, J. A., \& Villani, N. G. (2003). Soil moisture effect on Entomopathogenic nematodes. Environmental Entomology, 32: 80-87.

Gutierrez, A. P., Neuenschwander, P., \& Vanalphen, J. J. M. (1993). Factors affecting biological control of cassava mealybug by exotic parasitoids - a ratio-dependent supply-demand driven model. Journal of Applied Ecology, 30: 706-721.

Hala, N., Quilici, S., Gnago, A. J., N’Depo, O. R., N'D a Adopo A., Kouassi, P. \& Allou, K. (2004). 'Status of fruit flies (Diptera: Tephritidae) in Côte d'Ivoire and implications for mango Exports'. Fruits of Economic importance: from basic to applied knowledge, proceedings of the $7^{\text {th }}$ International Symposium on fruits flies of economic importance, 10-15 September 2006, Salvador, Brazil: 233-239.

Herrera, A. M., Dahlsten, D. D., Tomic-Carruthers, N., \& Carruthers, R. I. (2005). Estimating temperature-dependent developmental rates of Diorhabda elongata (Coleoptera: Chrysomelidae), a biological control agent of Saltcedar (Tamarix spp.). Physiological Ecology, 34: 775-784.

Holler, C., Borgemeister, C., Haardt, H. \& Powell, W. (1993). The relationship between primary parasitoids and hyperparasitoids of cereal aphids: an analysis of field data. Journal of Animal Ecology, 62: 12-21.

Koricheva, J., Larsson, S., \& Aukioja, E. H. (1998). Insect performance on experimentally stressed woody plants: a meta-analysis. Annual Review of Entomology, 43: 195-216.

Koumba, B. S. (2000). Étude comparative du comportement de recherche de l'herbivore des deux principaux ennemis naturels de la cochenille Phenacoccus manihoti Matile-Ferrero (Homoptera: Pseudococcidae) au Congo. MSc thesis, université Marien N'Gouabi, Pointe Noire (Congo), $77 \mathrm{p}$.

Kulkarni, A., \& Patel, I. S. (2001). Seasonal abundance of mustard aphid (Lipaphis erysimi) and associated bioagents in Indian mustard (Brassica juncea) crop. Indian Journal of Agricultural Sciences, 71: 681-682.

Le Rü, B., Iziquel, Y., Biassangama, A. \& Kiyindou, A. (1991). Variations d'abondance et facteurs de régula- tion de la cochenille du manioc Phenacoccus manihoti (Hom. Pseudococcidae) cinq ans après l'introduction d'Epidinocarsis lopezi (Hymenoptera : Encyrtidae) au Congo en 1982. Entomophaga, 36 : 499-511.

Li, H., Lascano, R. J., Wilson, L. T., \& Segarra, E. (2001). Semi-variance and cross-correlation of cotton canopy temperature, plant reflectance and soil properties in the landscape, in Precision Agriculture. Proc 3rd European Conference on Precision Agriculture Montpellier, France, ed. by Blackmore S and Grenier G. Agro-Montpellier, Montpellier, France pp. 241-246.

Li, H., Lascano, R. J., Booker, J., Wilson, T. L., Bronson, K. F., \& Segarra, E. (2002). State-space description of field heterogeneity: water and nitrogen use in cotton. Soil Science Society of America journal, 66: 585-595.

Li, H., Payne, W. A., Michels, J., \& Rush, C. M. (2006). Reducing plant water stress from attacks of greenbugs, corn leaf aphids and virus disease in dryland sorghum. $18^{\text {th }}$ World Congress of Soil Science, Philadelphia, PA. [Online]. Available: http://crops.confex.com/crops/wc2006/tech program/P15498. htm, p. 1930a. 
Luhanga, W. W., \& Gwinner, J. (1993). Mango mealybug (Rastrococcus iceryoides) on Mangifera indica in Malawi. FAO Plant Protection Bulletin, 41(2): 125-126.

Lunderstadt, J. (1998). Impact of external factors on the population dynamics of beech scale (Cryptococcus fagisuga) (Homoptera: Pseudococcidae) in beech (Fagus sylvatica) stands during the latency stage. Journal of Applied Entomology, 122: 319-322.

Macharia, I., Kimani, E., Koome, F., Kosiom, T., Heya, H., Otipa, M., \& Oronje, M. L. (2017) First Report and Distribution of the Papaya Mealybug, Paracoccus marginatus, in Kenya. Journal of Agricultural and Urban Entomology, 33(1):142-150.

Mani, M., \& Krishnamoorthy, A. (2007c). Biological suppression of Planococcus citri on acid lime with Cryptolaemus montrouzieri Mulsant in India. Entomoloy, 32: 221-24.

Mattiacci, L., Dicke, M. \& Posthumus, M. A. (1994). Induction of parasitoid attracting synomone in Brussels sprouts plants by feeding of Pieris brassicae larvae: role of mechanical damage and herbivore elicitor. Journal of Chemical Ecology, 20(9): 2229-2247.

Mattson, W. J., \& Haack, R. A. (1987). The role of drought in outbreaks of plant-eating insects. BioScience, 37: 110-118.

Moore, D. (1992). Lutte biologique contre la cochenille farineuse du manguier, In: Markham RH Wodageneh A. et Agboola S. (eds.), Manuel de lutte biologique, tome 2: Etudes de cas de lutte biologique en Afrique., IITA/CLBA, Cotonou, Bénin. 95-125.

Morris, R. J., Müller, C. B., \& Godfray, H. C. J. (2001) Field experiments testing for apparent competition between primary parasitoids mediated by secondary parasitoids. Journal of Animal Ecology, 70: 301-309.

Mukherjee, N. G. (1919). Handbook of Sericulture. Bengal Secretariate Press, Calcutta, pp. 121127.

Nébié, K. S., Nacro, L. C. Otoidobiga, Dakouo D. \& Somda, I. (2016) Population Dynamics of the Mango Mealybug Rastrococcus invadens Williams (Homoptera: Pseudococcidea) in Western Burkina Faso. American Journal of Experimental Agriculture, 11(6): 1-11.

Niesenbaum, R. A., \& Kluger, E. C. (2006). When studying the effects of light on herbivory, should one consider temperature? The case of Epimecis hortaria F. (Lepidoptera: Geometridae) feeding on Lindera benzoin L. (Lauraceae). Physiological Ecology 35: 600-606.

Noyes, J. S. (1988). Gyranusoidea tebygi sp. n. (Hymenoptera: Encyrtidae), a parasitoid of Rastrococcus (Hemiptera: Pseudococcidae) on mango in India. Bulletin of Entomological Research, 78: 313-316.

Peacock, L., Worner, S., \& Sedcole, R. (2006). Climate variables and their role in site discrimination of invasive insect species distributions. Environmental Entomology, 35: 958963.

Pires, A. S. S., Sujii, E. R., Fontes, E. M., Tauber, C. A., \& Tauber, M. J. (2000). Dry-season embryonic dormancy in Deois flavopicta (Homoptera: Cercopidae): roles of temperature and moisture in nature. Population Ecology, 29: 714-720. 
Pitan, O. O. R., Akinlosotu, T. A., \& Odebiyi, J. A. (2000). Impact of Gyranusoidea tebygi Noyes (Hymenoptera: Encyrtidae) on the mango mealybug Rastrococcus invadens Williams (Homoptera: Pseudococcidae) in Nigeria. Biocontrol Science and Technology, 10: 245-254.

Pitan, O. O. R., Mwansat, G., Akinyemi, S. O. S., Adebayo, O. S., \& Akinlosotu, T. A. (2002). Effect of mango mealybug and sooty mould attack on mango and the impact of the released Gyranusoidea tebygi Noyes on yield. Fruits (Paris), 57: 105-113.

Prokopy, R. J., \& Owens, E. D. (1983). Visual detection of plants by herbivorous insects. Annual Review of Entomology, 28: 337-364.

R Development Core Team (2012). R: A language and environment for statistical computing. R Foundation for Statistical Computing, Vienna, Austria. ISBN 3-900051-07-0, URL http://www.R-project.org/.

Salomon, O. D., Wilson, M. L., Munstermann, L. E., \& Travi, B. L. (2004). Spatial and temporal patterns of Phlebotomine sand flies (Diptera: Psychodidae) in a cutaneous leishmaniasis focus in northern Argentina. Journal of Medical Entomology, 41: 33-39.

Shonouda, M. L., Osman, S., Salama, O., \& Ayoub, A. (2008). Insecticidal effect of Chrysanthemum coronarium L. flowers on the pest Spodoptera littoralis boisd and its parasitoid Microplitis rufiventris Kok. With identifying the chemical composition. Journal of Applied Science, 8: 1859 - 1866.

Shree, M. P., \& Boraiah, G. (1988). Incidence of turka and bacterial blight on mulberry plants in Germplasm Bank. Current Science, 57 (22): 111-113.

Shrewsbury, P. M., Bejleri, K., \& Lea-Cox, J. D. (2004). Integrating cultural management practices and biological control to suppress citrus mealybug. In: proceeding of XXVI IHC Protected cultivation 2002: in search of structures, systems and plant Materials for sustainable greenhouse production. Acta Horticulturae, 633, ISHS.

Singh, L. B. (1968). The mango. Botany, Cultivation and Utilization. World Crop Books. Leonard Hill, London.

Singh, S. V., Kumar, J., Malik, Y. P., \& Bisen, R. S. (2000). Determination of economic threshold of Lipaphis erysimi (Kaltenbach) on mustard cultivars. India Journal of Entomology, 62: 196202.

Sriharan, T. P., Samsom, M. V., \& Krishnaswami, S. (1979). Studies on tukra disease of mulberry. India journal of Sericulture, 18: 78.

Suresh, S., \& Kavitha, P. C. (2008). Seasonal incidence of economically important coccid pests in Tamil Nadu. Branco M, Franco JC \& Hodgson C (eds) (2008) Proceedings of XI International Symposium on Scale Insect Studies, Oeiras (Portugal), 24-27 September 2007. ISA Press, Lisbon, 322 p.

Van Nouhuys, S., \& Hanski, I. (2000). Apparent competition between parasitoids mediated by a shared hyperparasitoid. Ecology Letters, 3: 82-84.

Van Veen, F. J. F., Rajkumar, A., Müller, C. B., \& Godfray, H. C. J. (2001). Increased reproduction by pea aphids in the presence of secondary parasitoids. Ecological Entomology, 26: 425-429. 
Venables, W. N., \& Ripley, B. D. (2002). Modern Applied Statistics with S. Fourth Edition. Springer ISBN 0-387-95457-0

Vennila, S., Deshmukh, A. J., Pinjarkar, D., Agarwal, M., Ramamurthy, V. V., Joshi, S., Kranthi, K. R., Bambawale, O. M. (2010). Biology of the mealybug, Phenacoccus solenopsis on cotton in the laboratory. Journal of Insect Science, 10 (115): 1-9.

Whiley, A. W. (1993). Environmental effects on phenology and physiology of mango-a review. Acta Horticulturae, 341: 168-176.

Williams, D. J. (1989). The mealybug genus Rastrococcus (Homoptera: Pseudococcidae). Systematic Entomology, 14: 433-486.

Williams, D. W., \& Liebhold, A. M. (2002). Climate change and the outbreak ranges of two North American bark beetles. Agricultural Forest Entomology, 4: 87-99.

Zuur, A. F., Ieno, E. N., Walker, N. J., Saveliev, A. A., \& Smith, G. M. (2009). Mixed effects models and extensions in ecology with R. New York, NY: Springer. 